\title{
Nietzsche's Antisociology: Subjectified Culture and the End of History ${ }^{1}$
}

\author{
Robert J. Antonio \\ University of Kansas
}

Although a very important figure in interdisciplinary social theory, Nietzsche is absent from sociological theory, especially in the United States. Equating rationalization with cultural homogenization and liquidation of particularity, Nietzsche saw "decadence" where modern social theorists saw progress. He held that sociology drapes cultural domination, regimentation, and exhaustion with the appearance of legitimacy. This essay explores his views about the depletion of social resources stressed in modern theory. It elaborates his "antisociology" and then traces the impact of this framework on three divergent currents of social theory. Nietzsche is read against the backdrop of modern theory in order to explore his continuing challenge to this tradition and his relevance to sociology.

Fundamental innovations: . . . In place of "sociology," a theory of the forms of domination. In place of "society," the cultural complex, as my chief interest. (Nietzsche, The Will to Power)

\section{INTRODUCTION}

\section{Nietzsche as Postmodern Precursor}

Culture has been a resurgent interest among sociologists for nearly a decade (e.g., Featherstone 1986; Robertson 1988; Alexander and Seidman 1990; Münch and Smelser 1993; Griswold 1994). This trend follows events outside the discipline that have made culture a hotly contested terrain: "culture wars" over diversity, the canon, political correctness,

${ }^{1}$ Many thanks to Alessandro Bonanno, Steve Best, Göran Dahl, Pat Johnston, Stephen Kalberg, Doug Kellner, Annette Kuhlmann, Ernest Manheim, Lawrence Scaff, David Smith, and Isidore Wallimann for their help on different drafts of this essay or with ideas central to my argument. Three $A J S$ reviewers also provided good critiques of the essay; it would have been stronger if I were able to engage all of their critical points. I especially want to thank Martin Riesebrodt for an extremely incisive critique that contributed substantially to the final version. Finally, I am in debt to Pasquale Caracciolo and Gary Shapiro for stirring my interest in Nietzsche; however, these friends are not to blame for my positions or errors. Direct correspondence to Robert J. Antonio, Department of Sociology, University of Kansas, 716 Fraser Hall, Lawrence, Kansas 66045-2172.

(C) 1995 by The University of Chicago. All rights reserved.

0002-9602/96/10101-0001\$01.50 
and cultural studies programs. Related battles rage over interdisciplinary social theories. Claiming to put social thought on fresh ground, new cultural theorists attack modern social theory, especially classical variants, for "essentialism," "foundationalism," "totalization," and obliteration of "difference" (i.e., of local, minority, and non-Western voices). ${ }^{2}$ Nietzsche, however, is largely unscathed by their broadsides. Rather, the new cultural theorists see him as their major precursor.

Nietzsche was practically unknown before madness permanently ended his writing in 1889 , but soon after that date he gained enormous international repute (e.g., Kaufmann 1974, pp. 418-20; Hughes [1958] 1977, pp. 336-91; Thatcher 1970; Nehamas 1985; Rosenthal 1986; Thomas 1986; E. Heller 1988; Aschheim 1992). ${ }^{3}$ Diverse thinkers believed that he posed a fundamental, subversive challenge to modern sociopolitical life by exposing how conservatism, reformism, and radicalism alike serve domination and mediocrity and by providing a missing optic illuminating hidden links between rationalization and mass regimentation. Sensing an unbridgeable gap between the promises and realities of mass democracy, they wanted something entirely new. In a passage suggestive of today's postmodern tendencies, Georg Simmel ([1900] 1978, p. 484) spoke of a "secret restlessness" or "helpless urgency" that pushes thinkers "from socialism to Nietzsche." In the wake of World War I and pervasive disenchantment with modern institutions and creeds, Thomas Mann stated aptly ([1918] 1983, p. 366) "I beg pardon for seeing Nietzsche everywhere, and only him."

${ }^{2}$ Poststructuralism and postmodernism (e.g., Michel Foucault, Jacques Derrida, Gayatri Spivak, Gilles Deleuze and Félix Guattari, Jean Baudrillard, Jean-Fançois Lyotard, Ernesto Laclau and Chantal Mouffe) are probably the most important new cultural theories, while, among many fusions, postmodern feminism has had wide impact (e.g., Nicholson 1990). In North America, these approaches have posed stiff challenges in the humanities (Berman 1988) and, more recently, in social anthropology (e.g., Clifford 1988; Keesing 1989; Shore 1988) and sociology (e.g., Denzin 1986; Seidman 1991; Seidman and Wagner 1991; Pfohl 1993). Modern social theory arose from Enlightenment thought and later positions that tempered its rational features. Classical theorists (e.g., Weber and Durkheim) addressed the overall path of modern social development empirically and normatively. Their work was more historical, systematic, and complex than their precursors (e.g., Adam Smith and Auguste Comte). Contemporary modern theorists (e.g., Daniel Bell and Jürgen Habermas) follow the tracks of classical theory but employ added resources from specialized science. Arguably, the classical phase began with Marx's analyses of the early, second industrial revolution (1840s-1860s), but most work was done after 1890 and before the rise of specialized social science in the 1920s and 1930s. Marx and Nietzsche are both transitional figures (Antonio and Kellner 1992).

${ }^{3}$ Bracketed dates, of course, refer either to the time of first publication or the year the work was written. For Nietzsche, separate dates are not provided for material added to the second edition (1887) of The Gay Science. Moreover, The Will to Power is composed of selections from Nietzsche's notebooks, arranged and published by Nietzsche's sister after his death. 
Hans-Georg Gadamer (1977, p. 116) saw Nietzsche as "the great, fateful figure who fundamentally altered the task of the critique of the subjective spirit of our century"; Karl Mannheim ([1936] 1955, pp. 309-11) argued that Nietzsche, along with Marx, began the "sociology of knowledge"; and Paul Ricoeur (1970, pp. 32-36) held that he initiated, with Marx and Freud, the hermeneutics of "suspicion." Treating conscious thought and morality as "surface" phenomena, Nietzsche made the representation of reality deeply problematic and shook modern theory's rational foundations. ${ }^{4} \mathrm{His}$ views about the entwinement of knowledge and power and the split between subjective experience and objective culture implied a radical crisis of representation and a need to "overcome" modern thought (e.g., Simmel [1907] 1991; Scaff 1989). Martin Heidegger ([1961] 1991b, pp. 6-8) held that Nietzsche pointed to a "consummation" of the "modern age" and a possible end of "Western history." Max Weber is purported to have said: "The honesty of a contemporary scholar . . . can be measured by the position he takes vis-à-vis Nietzsche and Marx. Whoever fails to acknowledge that he could not carry out the most important part of his own work without the work done by both, Marx and Nietzsche, deceives himself and others. The intellectual world in which we live is a world which to a large extent bears the imprint of Marx and Nietzsche."

However, in contrast to Marx, who has finally been included among the founders of "sociological theory," Nietzsche is glaringly absent from sociological discourse. In the United States, he is left out entirely, and elsewhere he is seldom discussed. ${ }^{7}$ While many nonsociologists (e.g., Sig-

4 Nietzsche anticipated core aspects of psychoanalytic theory; see Jones (1963, pp. 206-7, 276, 365), Sulloway (1979, pp. 467-68), Jung (1961, pp. 101-3, 153, 189, 207; [1921] 1976, pp. 136-46; [1934-39] 1988), and Hughes (1977, pp. 105-60).

${ }^{5}$ Reportedly, Weber said this to his students, shortly before his death, following a debate involving Oswald Spengler. The quote follows Wolfgang Schluchter's (1989, p. 316) translation of Eduard Baumgarten.

"I agree with Steven Seidman's (1991) distinction between "social theory" and "sociological theory"; the modern theory tradition described above is social theory even though important segments have been reframed and incorporated into sociology.

${ }^{7}$ In U.S. scholarship, Nietzsche does not appear in specialized theoretical work or theory texts. For example, Sorokin (1928; [1937] 1962) mentioned Nietzsche once in his comprehensive survey of sociological theory and only casually in his massive Social and Cultural Dynamics (even though Nietzsche has direct relevance for its central theme). His name appears only seven times, with no discussion, in more than a thousand pages of Becker and Barnes's ([1938] 1961) major history of social thought, which, in addition to sociologists, provides detailed coverage of diverse and often obscure philosophical, religious, and political thinkers. Similarly, he is mentioned only six times in roughly 2,000 pages of specialized essays edited by Barnes, Becker, and Becker (1940) and by Barnes (1948). These important works deal extensively with German social philosophy and social theory (e.g., Wundt, Dilthey, Rickert, Tönnies, Weber, Simmel, Stein, Troeltsch, Freud, Adler, Oppenheimer, and Freyer). In one essay, Becker (1940), making copious references to German texts and quoting Goethe in German at the head of each subsection, 
mund Freud, Alfred Marshall, Lewis Henry Morgan, and Wilhelm Wundt) and relatively minor thinkers (e.g., Ludwig Gumplowicz, Jacques Novicow, Othmar Spann, Célestin Bouglé, and Walter Bagehot) have often received close sociological attention, Nietzsche is usually ignored even in detailed analyses of the social theorists (e.g., Weber, Simmel, Scheler) he influenced. This is still the case today, in spite of the major resurgence of interdisciplinary interest in his social theory.

addressed thinkers such as Max Weber and Alfred Weber, Bücher, Schmoller, Löwith, Spengler, Barth, and Gogarten. Even pieces written by German scholars about theorists who borrowed broadly from Nietzsche (e.g., Scheler, Spengler) say little or nothing about his influence. Thus, the inattention to his work was hardly a product of ignorance of German language and thought. In another major volume, Salomon (1945), elaborating the history of German sociology, discussed sociological thinkers (e.g., Weber, Simmel, Scheler) and nonsociologists influenced by Nietzsche without mentioning him. In an essay on the sociology of religion, another German speaker discussed many nonsociologists with only one passing reference to Nietzsche (Wach 1945). Merton's (1945) treatment of the sociology of knowledge covered Scheler and other German thinkers with no mention of Nietzsche. Parsons's ([1937] 1968) and Bendix's (1960) pathbreaking studies, which introduced Weber to English-speaking audiences, mentioned Nietzsche only in passing. The massive Theories of Society (Parsons et al. 1961) had selections from philosophers, psychologists, historians, economists, theologians, and many other nonsociologists, but included nothing from Nietzsche. A brief essay on him appeared in the Encyclopedia of Social Science (Andler 1933), but he is absent from later works of a similar nature (see Sills 1968; Borgatta and Borgatta 1992). Early sociologists occasionally made passing objections to his positions on democracy (e.g., Cooley [1902] 1964, pp. 28-29), Christianity (e.g., Ross 1901, p. 425), and progress (e.g., Ward 1903, p. 231). Later, he was sometimes mentioned briefly in discussions of Ruth Benedict's ([1934] 1960) use of his concepts of "Appollonian" and "Dionysian" culture (earlier, Jung had employed them; see Jung 1976). Other passing references identify Nietzsche with racism, nationalism, militarism, fascism, and Nazism (e.g., Bernard 1939, p. 24; 1942, p. 539). Bogardus's (1948, pp. 366-67) superficial comments linked him to the Nazi regime; Martindale $(1960 ; 1981)$ also provided simplistic coverage; and Timasheff ([1955] 1967) ignored him completely as do most recent texts (e.g., Ashley and Orenstein 1985; Ritzer 1992; Turner 1991). Exceptions are Collins and Makowsky's ([1972] 1993, pp. 66-80) mostly biographical account and brief selections in Farganis's (1993, pp. 97-104) collection. More telling, however, is that Nietzsche is mentioned only in passing in Aron's ([1965] 1989) classic text (based on his lectures at the Sorbonne) and not at all in Münch and Smelser's Theory of Culture (1993). Lemert (1993) mentions his "marginalized" status, but still leaves him out of a collection aimed explicitly at breaking with the canonical narrative of sociological theory. Although I make no pretense of having scrutinized the entire history of American sociological theory, it is safe to say that Nietzsche has been left out of the story. Of course, there are exceptions, especially in Europe. For example, Lawrence E. Hazelrigg (1989), Michael Maffesoli (1991, 1993), Mike Gane (1992), Georg Stauth, and Bryan Turner (e.g., Stauth and Turner 1988, 1992; Turner 1982) address Nietzsche. Other sociologists, such as Anthony Giddens, David Frisby, and Wilhelm Hennis, also consider him as a context for their work. But such individuals usually work in the style of social theory. Even in Europe, Nietzsche tends to be ignored in sociological discussions, including discourses about thinkers he influenced (see Baier 1981-82). An important exception, published while this essay was under review, is the Canadian sociologist Irving M. Zeitlin's Nietzsche: A Re-Examination (1994). 


\section{Exploring Nietzsche's Antisociological Challenge}

Even the ideals of science can be deeply, yet completely unconsciously influenced by decadence: our entire sociology is proof of that. . . . It knows only the form of decay of society, and inevitably it takes its own instincts of decay for the norms of sociological judgment. (Nietzsche, The Will to Power)

In a classic study of late 19th- and early 20th-century social theory, H. Stuart Hughes (1977, pp. 34, 104-5) found numerous theorists "elaborating more rigorously and systematically" positions that "Nietzsche had thrown out in fragmentary form." But he stressed that Nietzsche's specific impact on thinkers is hard to disentangle from that of the larger cultural climate he helped forge. His fragmented, contradictory, and "open" texts welcome diverse interpretations, selective appropriations, and disjunctive fusions. Consequently, his impact has been as ambiguous as it has been pervasive and manifold. For example, he has been both widely appropriated and attacked by feminist theorists. ${ }^{8}$ Even his selfproclaimed followers (whom he forswore) have been diverse and contradictory. Nietzsche's ideas have "commingled" with many divergent approaches and have operated as "an inspirational subtext" or "pervasive atmospheric presence" (Aschheim 1992, pp. 2, 59). As Foucault (1989, p. 247) held, "There is not just one Nietzscheanism. One cannot say there is a true Nietzscheanism and that this one is truer than the other."

Still, Nietzsche casts a distinctive shadow in social theory. Seeing him as the primary godparent of the sociology of culture, Horst Baier stressed

${ }^{8}$ Nietzsche's views about women are highly ambiguous and deeply problematic; interpretations of his positions on gender and his use of mašculinist metaphors vary widely and are the subject of intense disagreements that are difficult to summarize. For different perspectives, see Derrida (1979), Thomas (1986, pp. 132-41), Schutte (1986, pp. 176-85), Gilman (1987), Graybeal (1990), Ackerman (1990, pp. 122-37), Irigaray (1991), Gane (1992), Patton (1993), Kofman (1993), Burgard (1994). Contradictory readings also abound in other areas. For example, during World War I, John Dewey and George Bernard Shaw connected him to antinationalist and antiauthoritarian views, while Durkheim and many British thinkers tied him to German militarism (Durkheim [1916] 1986, p. 232; Dewey [1916] 1985, pp. 220-21; Thomas 1986, pp. 125-31; Thatcher 1970, pp. 175-268). Different critics see diverse pathologies emanating from Nietzsche's work, but all agree that it has had enormous impact. Karl Löwith (1966, p. 16) asserted that his "ideas paved the way to the Third Reich"; Georg Lukàcs ([1962] 1980, pp. 309-99) saw him as the master theorist of irrationalism and the imperialist phase of capitalism; Habermas (1987a) held that he began a postmodern regress from democratic thought; Carl Schmitt ([1925] 1986, p. 20) considered him a "high priest," who stirred dangerous currents of "political romanticism"; and Leo Strauss $(1989$, pp. 24-26, 31) described him as "the philosopher of relativism" and linked him to fascism. On Nietzsche and politics, see Kaufmann (1974), Hughes (1977, pp. 336-431), Love (1986), Schutte (1986), Thomas (1986), Strong (1988), Warren (1988), Dürr (1988), Lapenies (1988), P. Heller (1988), Pütz (1988), Taylor (1990), Aschheim (1992). 
his formative impact on some of the greatest German-speaking theorists (i.e., Weber, Simmel, Scheler, Tönnies, Freyer, Mannheim). Echoing Weber, Baier held that Marx and Nietzsche raise the most fundamental questions for social theory. Yet, while Marx's contribution has been acknowledged, Nietzsche is still ignored in recent sociology. Baier recognized the difficulties inhering in efforts to elaborate Nietzsche's indirect impact on social theory. But he suggested that asking how Nietzsche posed "the question of society" and following "traces" of his ideas in works of important theorists would help clarify his contribution. Both strategies will be employed in this article (Baier 1981-82, pp. 25, 27, 32-33). In addition, however, the "sociological" vision Nietzsche opposed will be entertained to draw out his challenge to modern social theory.

Regardless of many differences, classical theorists converged around some, central sociological presuppositions, questions, and themes. They embraced "progressive" features of sociocultural differentiation or, at least, viewed certain, consequent, social conditions or capacities as civilizing forces. Most implied that the process shatters the rigid, parochial constraints of tradition, shaping individuality in a freer, richer, social way. Divergent values, norms, and ideas give rise to multifaceted, reflexive, and autonomous social selves who are capable of communicating effectively with ever more diverse types of people across highly specialized roles. They forge highly complex cooperative networks that generate new social powers and consequent geometric advances in productivity. Classical theorists saw their normative critiques to be anchored in nascent forms of legitimate authority inhering in the new types of social interdependence and solidarity. While also warning of looming threats and pathologies, even pessimists detected vital, new social resources (e.g., social science) to moderate crises, reduce coercion, and strengthen the new modes of legitimate authority. Overall, they believed that rationalization unleashes social forces of universal significance, which, if properly directed, would liberate and nurture human particularity. ${ }^{9} \mathrm{By}$ contrast, Nietzsche equated rationalization with cultural homogenization and liquidation of particularity. He saw "decadence" where classical theorists saw progress. In his view, sociology drapes sweeping cultural domination, regimentation, and exhaustion with the appearance of legitimacy.

This essay will explore Nietzsche's views about the absence of the social resources claimed by modern theorists and his inversion of their most basic perspectives about modernity. It will elaborate his "antisociology," and then trace its impact on three divergent currents of social

${ }^{9}$ This is an extremely simplified summary of a very complex discursive field. For more detailed discussion, see Antonio and Kellner (1992), Kloppenberg (1986). 
theory. Contrasting themes from modern theory will be addressed at key junctures of both sections. While my intent is to address some possibly revealing threads of Nietzsche's social theory and to clarify his relevance for sociology, the reader must be cautioned about the many unresolved riddles, ambiguities, and contradictions in his texts. Any consistent reading risks harmonizing tensions he wanted to remain problematic. In this essay, however, he is read against the backdrop of modern theory in order to explore his continuing challenge to this tradition.

\section{NIETZSCHE'S ANTISOCIOLOGY}

\section{The Socratic Culture Complex: The End of Particularity}

One should inaugurate culture in the right place-not in the "soul" . . . [but in] the body, demeanor, diet, physiology: the rest follows. . . . Christianity, which despised the body, has up to now been mankind's greatest misfortune. (Nietzsche, Twilight of the Idols)

Nietzsche rejected the enduring Western conception of the "rational subject," which portrays reason or mind as a "higher" faculty governing the body. He was especially critical of the new version of the subject or the social self, emergent during his own day. Holding that "every association" makes strong individuals "shudder slightly" and that "all contact . . . 'in society'-involves inevitable uncleanliness," Nietzsche identified individuality with bodily "intelligence" and "multiplicity." Consequently, he viewed the genuine "self" to be a nonsocial, irreducible, individual particularity and contradictory to the "herd"-like "ego" (i.e., the social self). Nietzsche believed culture to originate from and to regulate the body. Superior cultures nurture particularity by providing resources to express bodily drives in a "spiritualized" way that favors pleasure and "ascending life." Although these cultures provide healthy individuals resources to express themselves vitally and creatively, they also exert "domestication" that constrains the destructive inclinations of the "weak." Some cultures, however, domesticate so thoroughly and repress bodily drives so severely that the "herd instinct of obedience" and consequent guilt, illness, and "nihilism" prevail (Nietzsche [1882] 1974 , p. 342 ; [1883-85] 1969c, pp. 61-66, 86, 118, 120; [1883-88] 1968b, pp. 203-4, 347-49, 363; [1886] 1966, pp. 26, 110-11, 226; [1888] 1968a, pp. 29-44).

The overarching "moral" regulation of inferior cultures is animated by ressentiment (i.e., the inclination of the weak to make their suffering meaningful by blaming others and taking "imaginary revenge"). According to Nietzsche, "ascetic priests" attain cultural leadership by manipulating this sentiment, creating normative systems or "slave morali- 
ties" that promise salvation for the obedient and punishment for the dissolute. By intensifying and redirecting ressentiment inward against the blameworthy body and outward against collective enemies, morality forges powerlessness into mass discipline and the weak into a society (Nietzsche [1887] 1969b, pp. 36-37, 116-18, 125-27; 1968b, p. 156). Moreover, healthy, uninhibited individuals are made prime targets of ressentiment and coercion. Bound by slave morality, the herd collects and defeats the "strong." Thus, Nietzsche reverses Spencerian "survival of the fittest" because in his view social "selection" favors the weak (Nietzsche 1968b, pp. 55, 75, 343, 361-65, 479; 1968a, pp. 75-76).

According to Nietzsche, Western culture breeds especially powerful, unhealthy ressentiment. He argued that Socrates, an ingenious ascetic priest, initiated the "modern" or "Socratic" culture complex, giving "reason" absolute dominion over the body and, thereby, taming the explosion of impulses and desires unleashed by the collapse of Greek antiquity. Socrates' equation of truth and virtue with disembodied reason gave rise to the West's characteristic splits between mind and body, subject and object, and theory and practice. Socratic culture's brutal domestication turns drives "backward" against the body, creating crippling "inwardness" and "self-laceration" (Nietzsche [1872] 1967; 1968b, pp. $156,202-3,328 ; 1969 b$, pp. 84-85; 1968a, pp. 29-34).

Nietzsche saw Christianity as the prototypical slave morality. Its democratic ethos, which provided the ultimate roots of bourgeois and socialist ideals, greatly magnified original Socratic ressentiment. The promise of equality and salvation to all the "subjugated and oppressed" and of eternal damnation to all nonbelievers demanded unparalleled denial of the body, absolute obedience, "mortal hostility to reality," and "hatred of those who think differently" and of "multiplicity." Protestantism made matters worse. Regardless of contributions to "mobility," "liberty," and "science," the Reformation made everyone his or her own priest, generating methodical self-regulation in the herd and brutal violence against the strong. According to Nietzsche, the Protestant "north" is the heartland of Socratic culture (Nietzsche 1974, pp. 293, 310-13; 1968a, pp. 131-39, 184-86).

Nietzsche held that Christianity subordinated family, locality, ethnicity, and nation to the most universal cultural domination the world had ever known. In his view, however, the Enlightenment and bourgeois revolutions made the process even more extensive and inclusive. While promising earthly salvation, the new "democratic" creeds (e.g., positivism, utilitarianism, feminism, Spencerianism, socialism, ad infinitum) secularize and pluralize slave morality and institute much more systematic, diffuse social control. Explosive sociocultural differentiation, celebrated by modern theorists, multiplies, disperses, and specializes the sites 
for ressentiment, asceticism, and discipline. Rather than genuine diversity, it produces nearly identical "useful, industrious, handy, multipurpose herd animal[s]." Nietzsche's charge that "the whole of sociology" draws its norms from "decaying forms of society" means that it reflects and serves Socratic rationalization. His vision of global liquidation of individuality and cultural particularity contradicts modern theory's grand narrative of rationality, freedom, and progress. Attributing the conditions to enduring aspects of Western civilization, he envisioned a much deeper crisis than modern theorists ever imagined (Nietzsche 1966, pp. 176-77; 1968a, p. 91; 1968b, pp. 478).

\section{The End of the Social/Cultural Exhaustion}

All of us are no longer material for a society. (Nietzsche, The Gay Science)

Nietzsche held that the current wave of rationalization has depleted culture so severely that virtually all of "our institutions are no longer fit for anything" (Nietzsche 1968a, p. 93). Because "shared" values, norms, and ideas are no longer binding, culturally reproduced social integration has dissolved. Rather than being normatively regulated, uncoerced behavior follows the grooves of habit, organizational routine, and mass culture or is simply disoriented (Nietzsche 1974, pp. 302-4, 338; 1969b, pp. $121-26 ; 1969 c$, p. $226 ; 1968 b$, p. 150).

For institutions to exist there must exist the kind of will, instinct, imperative which is anti-liberal to the point of malice: the will to tradition, to authority, to centuries-long responsibility, to solidarity between succeeding generations backwards and forwards in infinitum. . . . The entire West has lost those instincts out of which institutions grow, out of which the future grows. ... One lives for today, one lives very fast-one lives very irresponsibly: it is precisely this which one calls "freedom." That which makes institutions institutions is despised, hated, rejected: whenever the word "authority" is so much as heard one believes oneself in danger of a new slavery. (Nietzsche 1968a, pp. 93-94)

The state's newly developed top-to-bottom officialdom is emblematic of this sweeping disintegration; its arsenal of disciplinary mechanisms fill the breach left by the lack of legitimate authority. Nietzsche held that the state and culture are inherent "antagonists." Pointing to the cultural stagnation that followed Germany's victory in the Franco-Prussian War, he stated, "Coming to power is a costly business: power makes stupid. . . The Germans-once they were called a nation of thinkers: Do they still think at all? Nowadays the Germans are bored with intellect, ... politics devours all seriousness for really intellectual things- 
Deutschland, Deutschland über alles was, I fear, the end of German philosophy" (Nietzsche 1968a, p. 60). Immobilizing intellectual and aesthetic creativity, the power state manipulates through a new mix of draconian law, welfare provision, propaganda, and nationalism. It is a "new idol" and the focal point of dangerous currents of mass ressentiment and regimentation (Nietzsche [1873-76] 1983, pp. 3-6; 1969c, 75-78; [1883] $1968 b$, p. 48; [1888] 1982b; [1888] 1967; 1968a, 62-63; [1888], 1969a, p. 319).

Nietzsche viewed socialism as an outgrowth of Socratic culture's democratic ethos and expansionary state. ${ }^{10}$ The self-righteous egalitarian, collectivist, and redemptive thrust of socialism's highly secularized Christian ressentiment makes it all the more dangerous. Because socialists simply want to manage "more cheaply, more safely, more equitably, more uniformly," Nietzsche argued, they would, if they came to power, amplify all the pathologies inherent in "state power." He held that socialism is a "younger brother" of ancient despotism, promising "iron chains," "fearful discipline," "abolition of the individual," and "complete subservience." It would re-create "Chinese conditions" of enduring stasis and absolutism (Nietzsche [1878-80] 1986, pp. 173-74; [1881] $1982 a$, pp. $83,109,126-27$; 1974, pp. 99, 338; 1968b, pp. 77-78, 463-64).

In contrast to modern theorists, even Marx, Nietzsche did not see anything redeeming about capitalism. Thus, his antistate and antisocialist views had nothing to do with classical liberalism. He loathed capitalism's overarching impersonalism and instrumentalism, holding that they turned everyone into "industrious ants" (Nietzsche 1982a, pp. 12627). In one work, he followed his critique of the state with a blistering attack on "the flies of the marketplace," stressing their falseness, petty ambitiousness, baseness, capriciousness, and sycophancy. Capitalism produces all-encompassing haste, superficiality, and life-denying specialized labor. Worse off than slaves, wage workers are at the "mercy of brute need" and employers who ruthlessly "exploit" them. Nietzsche considered capitalism's so-called culture to be completely vulgarized and debased (Nietzsche 1983, pp. 164-65; 1986, p. 167; 1974, pp. 107-8; $1969 b$, pp. 78-81, 227, 258-59, 296-97). Suggesting a Marcusean "great refusal," he urged that "workers of Europe ought henceforth to declare themselves as a class a human impossibility and not, as usually happens, only a somewhat harsh and inappropriate social arrangement; they ought to inaugurate within the European beehive an age of a great swarming-

${ }^{10}$ Nietzsche did not explore specific socialist programs, Marx, or Marxism (Kaufmann 1974, p. 292n.7). Also, his ideas overlap with Marx's positions at some key points; see Love (1986). 
out such as has never been seen before, and through this act of free emigration in the grand manner to protest against the machine, against capital, and against the choice now threatening them of being compelled to become either the slave of the state or of the party of disruption" (Nietzsche 1982a, pp. 125-27).

Against social Darwinist claims that capitalist competition produces "the fittest" individuals, Nietzsche held that it gives rise to "smaller . . . more governable" types. Capitalism's formal equality, relativistic interdependence, and instrumentalism level status and value hierarchies, reduce tastes to the lowest common denominator, and destroy cultural constraints on ressentiment. This complete evaporation of legitimate authority provides nearly unlimited opportunities for the ascent of frauds and mediocre herd leaderships. Thus, Nietzsche cleaved modern theory's connections between capitalism, autonomous individuality, and progress. Liberalism and socialism both manifest fundamental pathologies of the same exhausted cultural complex (Nietzsche 1974, p. 202; 1968b, pp. 55, $75,79)$.

Nietzsche ridiculed the positivist dream of substituting science for religion, seeing it as a gross deception illustrative of the depth of cultural exhaustion. He detested positions that treated science as an independent worldview and ignored its need for presuppositions (a "philosophy" or "faith" to give it "a direction, meaning, a limit, a method, a right to exist"). In a biting passage about an expert researcher on the "leech's brain," he satirized the tunnel vision of narrowly specialized science. Its "faith in truth," stoical discipline, and narrow purview betray its hidden roots in priestly asceticism. Although admiring the inexorable honesty of properly practiced specialized science, Nietzsche held that it has no inherent meaning-its value depends entirely on its consequences for life. Science becomes trivial or dangerous when its problems, programs, and knowledge are considered to be value free or to be a source of values. The idea of science imperiously directing social life justifies Socratic discipline and control. Such pseudoscience is no tonic for cultural crisis. Rather, animate culture and legitimate authority must be created to give science meaning and direction and to curb its destructive impulses (Nietzsche 1969c, pp. 261-64, 311-13; 1969b, p. 152).

"All honor to the ascetic ideal insofar as it is honest! So long as it believes in itself and does not play tricks on us!" Nietzsche (1969b, pp. 158-59) declared. While he preferred genuine Christian conviction to the new slave moralities, he felt that faith in God had already collapsed and that religion, like other creeds, is no longer practiced sincerely. In his view, the most obvious sign of decadence is that people regularly act according to beliefs they know are false. Nihilistic "forgery in ideals," ethical formality, and indolence prepare the way for a new type of tyr- 
anny, foreshadowed by Germany's peculiar mixture of reactionary conservatism, philosophic idealism, public welfare, delusions of national grandeur, anti-Semitism, and brute coercion. More generally, however, throughout the West, Socratic rationalization, in its most decadent stage, levels completely the particularities that give individuals and cultures strength and vitality. The sweeping exhaustion makes possible nightmarish future regimes (Nietzsche 1974 , pp. $310-13 ; 233 ; 1968 b$, p. $75 ; 1968 a$, pp. 149-50).

\section{Cultural Rationalization contra Communication}

Everywhere language is sick, and the oppression of this tremendous sickness weighs on the whole of human development. (Nietzsche, Untimely Meditations)

Privileging aesthetic experience over rational action, Nietzsche subverted modern theory's largely normative and instrumental views of communication and social bonds. He held that genuine human relationships are rooted in mutual feelings and the body and depend on the "superabundance of means of communication" offered by aesthetic sensibilities. By contrast, he treated language primarily as an instrument of social control. Being abstract and collective, "words" inevitably undermine the expression of the particularities that animate interpersonal ties. In intimate relationships, it is easy to detect that words fail to communicate adequately "feelings, intentions, nuances, desires, and fears." But if one openly acknowledges these silences, he or she risks being branded as "strange" and "isolated"; superior beings' authenticity opens them to the predations of the herd (Nietzsche 1974, pp. 297-300; 1968b, pp. 50, 203-4, 275, 334, 358, 371, 427-28; 1966, p. 217).

In Nietzsche's view, language produces "a separate world beside the other world, a place it took to be so firmly set that, standing upon it, it could lift the rest of the world off its hinges and make itself master of it. . . . Man has for long ages believed in the concepts and names of things as in aeternae veritates. . . . He really thought that in language he possessed knowledge of the world. The sculptor of language was not so modest as to believe that he was only giving things designations, he conceived rather that with words he was expressing supreme knowledge of things" (Nietzsche 1986, p. 16).

Treating words as mirrors of reality provides a comforting illusion of "certainty." This tendency obscures the social bases of language, reifies social conventions, and weakens capacities to imagine and create alternative conditions. Linguistic "abbreviations" cement obligatory social ties where "mutual agreement" about "feelings" is absent and the tendency to "let go" must be stemmed. Nietzsche held that language serves social 
selection of the herd, keeping experiences, desires, impulses, and actions of weak persons within boundaries, inscribing strong individuals as collective enemies, and redirecting ressentiment into regimentation. Accordingly, cultural rationalization makes this process of liquidating particularity more effective and universal (Nietzsche 1966, pp. 100-102, 216-17; $1968 b$, pp. 357-58, 380).

Since Nietzsche was himself a master writer, his polemics about words per se are hyperbolic. " The real target is Socratic culture's exceptionally abstract languages, rampant conceptual reifications, and impoverished aesthetic sensibilities. Nietzsche believed that the obsession with rational representation makes the body an inert target of disciplinary control. Adoration of concepts, theory, and reason makes the abstract signifier the ultimate object of knowledge. Purely formal concepts are treated as the "highest," "real," and "true" things, while sense experience is relegated to the degraded status of "appearance." Platonic ideas, Christian soul, Kantian things-in-themselves, and Newtonian atoms and time are all foundational reifications that "dehistoricize" the corporeal world and erect illusions of firm "grounds" for those who cannot face life without God and tradition or bear the weight of its conflictive choices and its "great dice game" (Nietzsche 1974, pp. 287-90; 1968b, p. 549; $1968 b$, pp. 35-37).

Destroying Socratic culture's "objective" foundations (i.e., God and Truth), the latest phase of cultural rationalization greatly amplifies feelings of uncertainty. The consequent desperate searching and clinging produces frenetic reification; fanatical new prejudices, religions, and politics appear alongside the most sterile intellectual formalisms. Mass culture's hastily formulated languages blur all difference and ambiguity (e.g., parties "transform their principles into great al fresco stupidities"). The proliferation of abstract signifiers, arising from diverse locations and detached from any sense of stable referents, contribute to increasingly mechanical, diffuse, and mindless regimentation. In this fashion, Nietzsche severed the links that modern theorists saw between rationalization and enhanced communication, social integration, and legitimate authority (Nietzsche 1983, p. $215 ; 1986$, pp. 161-62; 1966, pp. 216-17; $1968 b$, pp. 357-58, 380-81).

Subjectified Culture: Social Selves as Simulators

The phenomenon of modern man has become wholly appearance; he is not visible in what he represents but rather concealed by it. (Nietzsche, Untimely Meditations)

${ }^{11} \mathrm{He}$ advocated writing in a style that proves "one believes in an idea; not only thinks it but also feels it" (personal communication to Lou Andreas-Salomé, quoted in [1894] 1988, pp. 77-78). 
According to Nietzsche, the "subject" is Socratic culture's most central, durable foundation. This prototypic expression of ressentiment, master reification, and ultimate justification for slave morality and mass discipline "separates strength from expressions of strength, as if there were a neutral substratum . . . free to express strength or not to do so. But there is no such substratum; there is no 'being' behind the doing, effecting, becoming; 'the doer' is merely a fiction added to the deed" (Nietzsche 1969b, pp. 45-46). Leveling of Socratic culture's "objective" foundations makes its "subjective" features all the more important. For example, the subject is a central focus of the new human sciences, appearing prominently in its emphases on neutral standpoints, motives as causes, and selves as entities, objects of inquiry, problems, and targets of care (Nietzsche 1966, pp. 19-21; 1968a, pp. 47-54). Arguing that subjectified culture weakens the personality, Nietzsche spoke of a "remarkable antithesis between an interior which fails to correspond to any exterior and an exterior which fails to correspond to any interior" (Nietzsche 1983, pp. 78-79, 83).

The "problem of the actor," Nietzsche said, "troubled me for the longest time." $12 \mathrm{He}$ considered "roles" as "external," "surface," or "foreground" phenomena and viewed close personal identification with them as symptomatic of estrangement. While modern theorists saw differentiated roles and professions as a matrix of autonomy and reflexivity, Nietzsche held that persons (especially male professionals) in specialized occupations overidentify with their positions and engage in gross fabrications to obtain advancement. They look hesitantly to the opinion of others, asking themselves, "How ought I feel about this?" They are so thoroughly absorbed in simulating effective role players that they have trouble being anything but actors-"The role has actually become the character." This highly subjectified social self or simulator suffers devastating inauthenticity. The powerful authority given the social greatly amplifies Socratic culture's already self-indulgent "inwardness." Integrity, decisiveness, spontaneity, and pleasure are undone by paralyzing overconcern about possible causes, meanings, and consequences of acts and unending internal dialogue about what others might think, expect, say, or do (Nietzsche 1983, pp. 83-86; 1986, pp. 39-40; 1974, pp. 302-4, 316-17).

Nervous rotation of socially appropriate "masks" reduces persons to hypostatized "shadows," "abstracts," or simulacra. One adopts "many roles," playing them "badly and superficially" in the fashion of a stiff "puppet play." Nietzsche asked, "Are you genuine? Or only an actor?

12 The important passages on actor and role in The Gay Science were added to the second edition in 1887 and, thus, reflect Nietzsche's mature thought. 
A representative or that which is represented? ... [Or] no more than an imitation of an actor?" Simulation is so pervasive that it is hard to tell the copy from the genuine article; social selves "prefer the copies to the originals" (Nietzsche 1983, pp. 84-86; 1986, p. 136; 1974, pp. 23233,$259 ; 1969 b$, pp. $268,300,302 ; 1968 a$, pp. 26-27). Their inwardness and aleatory scripts foreclose genuine attachment to others. This type of actor cannot plan for the long term or participate in enduring networks of interdependence; such a person is neither willing nor able to be a "stone" in the societal "edifice" (Nietzsche 1974, pp. 302-4; 1986a, pp. 93-94).

Superficiality rules in the arid subjectivized landscape. Neitzsche $(1974$, p. 259$)$ stated, "One thinks with a watch in one's hand, even as one eats one's midday meal while reading the latest news of the stock market; one lives as if one always 'might miss out on something.' 'Rather do anything than nothing': this principle, too, is merely a string to throttle all culture. . . . Living in a constant chase after gain compels people to expend their spirit to the point of exhaustion in continual pretense and overreaching and anticipating others."

Pervasive leveling, improvising, and faking foster an inflated sense of ability and an oblivious attitude about the fortuitous circumstances that contribute to role attainment (e.g., class or ethnicity). The most mediocre people believe they can fill any position, even cultural leadership. Nietzsche respected the self-mastery of genuine ascetic priests, like Socrates, and praised their ability to redirect ressentiment creatively and to render the "sick" harmless. But he deeply feared the new simulated versions. Lacking the "born physician's" capacities, these impostors amplify the worst inclinations of the herd; they are "violent, envious, exploitative, scheming, fawning, cringing, arrogant, all according to circumstances." Social selves are fodder for the "great man of the masses." Nietzsche held that "the less one knows how to command, the more urgently one covets someone who commands, who commands severelya god, prince, class, physician, father confessor, dogma, or party conscience." The deadly combination of desperate conforming and overreaching and untrammeled ressentiment paves the way for a new type of tyrant (Nietzsche 1986, pp. 137, 168; 1974, pp. 117-18, 213, 288-89, 303-4).

Sovereign Selves: Dissimulators/Perspectival Beings

The age of Socratic man is over. (Nietzsche, The Birth of Tragedy)

Opposing the tide of subjectified culture, Nietzsche envisioned a "sovereign" type of individual who is not taken over by roles but acts according 
to his or her inherent bodily "intelligence" and "multiplicity." Sovereign individuals escape the social self's characteristic dualisms (e.g., mind/ body, inner/outer, and being/appearance) and consequent estrangement. They "dissimulate" to establish "distance" from their roles, discerningly staging, watching, and concealing themselves in "good conscience" to escape domestication, exert command, express benevolence and modesty, seek solitude, avert unnecessary conflicts, or just enjoy the freedom and playfulness of masks (Nietzsche 1986, p. 136; 1982a, p. 156; 1974, pp. 130-33, 169, 266, 302-4, 316-17, 321; 1968b, pp. 292-93; 1966, p. $160 ; 1969 b$, pp. 59-60). They "become those who we arehuman beings who are new, unique, incomparable, who give themselves laws, who create themselves" (Nietzsche 1974, p. 266).

While always rare, sovereign individuals can be found in all sorts of settings and strata. For example, strong persons in subjugated groups (including, according to Nietzsche, lower classes, Jews, and women), hardened by continuous struggles with highly unfavorable circumstances, often become skilled dissimulators (Nietzsche 1974, p. 317). Cultural complexes, however, vary greatly with respect to resources for nurturing sovereign individuality. "Tragic culture" of ancient Greece (Odysseus was Nietzsche's prototypic dissimulator) was exceptionally rich in this regard, while Socratic culture is impoverished. Today, the "fittest" individuals are treated as the "most deviant" types and prime enemies of the herd. Even in this setting, however, a few survive by employing all their powers of dissimulation and self-mastery. Endless struggles against a vast array of homogenizing and coercing forces make them "strong as the devil." Thus, even highly negative conditions give rise to a small number of "exceptional human beings" (Nietzsche 1968b, pp. 80, 46064 ; 1966, pp. 110-14, 137-39, 176-77; 1968a, pp. 118; 1969a, pp. 232; 253-55).

The current mixing of peoples and cultures draws out the worst instincts of weak individuals, but makes sovereign types "stronger and richer than ever before." The experience of diverse values, norms, and ways of life makes them flexible, adaptable, multisided, and "increasingly independent of any determinate milieu" (Nietzsche 1966, pp. 17477). Nietzsche stated: "Like trees we grow . . . not in one place only but everywhere, not in one direction but equally upward and outward and inward and downward; our energy is at work simultaneously in the trunk, branches, and roots; we are no longer free to do only one particular thing, to be only one particular thing" (Nietzsche 1974, pp. 332-33). This plural nature opens sovereign types to "the perspective character of existence"; they recognize that each person's body, biography, and location are unique optics, that superior culture originates from this 
purely historical matrix, and that cultural experience is itself refracted by the same particularities. Sovereign individuals embrace the plurality of possible beings, experiences, and perspectives (Nietzsche 1974, pp. $215,336-37)$. The "highest" type of person, Nietzsche held, would have "the greatest multiplicity of drives in the relatively greatest strength that they can be endured." Being the "richest in contradictions," he or she would have "antennae for all types" of humanity (Nietzsche 1968b, pp. $150,479,504-19$; 1966, pp. 50-51, 145-50, 160, 220-21, 226).

Nietzschean perspectivism is sometimes interpreted as giving equal validity to all points of view (i.e., only abstract "difference" stands above an otherwise flattened plane). Nothing is further from Nietzsche's (e.g., 1969a, p. 280) position. He equated relativism with intellectual and ethical indolence and saw it to be at the root of the war on difference. The consequent eclipse of "distance," or will to distinguish between superior and inferior values and people, opens the way for demagoguery, fraud, and coercion. If values are leveled, how can one be expected to choose conditions and leaders favoring tolerance and nurturance of particularity? Diverse value preferences naturally arise from healthy bodies and different social locations. But they also can reflect poor health and ressentiment. Therefore, all values should not be given equal validity. For this reason, Nietzsche called for a new "ordering of rank: not . . . an individualistic morality" (Nietzsche 1968b, pp. 162, 197; 1966, pp. 53-56, 148).

Perspectivism is "a complex form of specificity" converse to the prevalent reification of abstract concepts. Nietzsche said, "One has to learn to see . . . habituating the eye to repose, to patience, to letting things come to it, learning to defer judgement, to investigate and comprehend the individual case in all its aspects . . . not to react immediately to a stimulus, but to have the restraining, stock-taking instincts in one's control. ... In an attitude of hostile calm one will allow the strange, the novel of every kind to approach" (Nietzsche 1968a, p. 65). Engaging genuine difference requires a disciplined self-command, unknown to hasty, superficial simulators. Sovereign individuals are perspectival beings, expressing rigor in observing, reflecting, and acting. Their "will to power" derives as much from their refined capacity to create distance, withhold response, and grasp particulars as from their vital instincts.

Nietzsche did not reject science per se. Rather, his scathing attacks on positivist claims about science mirroring the world, revealing the meaning of history, and replacing religion deconstructed the pseudoscientific subject (i.e., the disembodied eye spectating neutrally on an autonomous, object world). He called for a more open, active, and specific way of knowing, stressing "experimental" understanding of human action and 
its consequences. ${ }^{13}$ Perspectivist science rejects the "world of truth" in "reverence" for all that "lies beyond" its "horizon" and for life's "rich ambiguity." It challenges reifications, clarifies the limits of rationality, opens multiple realities to view, and enhances particularity (Nietzsche 1974 , p. 335 ; 1968b, p. 340; 1968a, pp. 122-26, 162-65, 170-75). Nietzsche had this position in mind when he spoke of science being a sign of "a higher multiplicity of culture," and praised its "disciplining of the intellect, clarity, and severity in matters of intellectual conscience, noble coolness, and freedom of the intellect" (Nietzsche 1968b, p. 246; 1968a, p. 163).

Even perspectivist science, however, cannot solve the problem of Socratic rationalization, which endlessly strips away "veils," finds nothing underneath, and levels differences. Without proper direction, science feeds nihilism and cultural exhaustion. But if science is not an independent worldview, what values should guide it? Here, Nietzsche returned to the body and cultural sublimation of drives in the cause of "ascending life." Aesthetic sensibilities and art, he argued, are the real enemies of the rational subject and the ultimate source of individual and cultural vitality. Science's "will to truth" originates from the ascetic ideal, while art derives from a "will to deception" with "a good conscience" (Nietzsche 1969b, pp. 153-56; 1982b, p. 682). Nietzsche asserted that "we need all exuberant, floating, dancing, mocking, childish, and blissful art lest we lose our freedom above things that our ideal demands of us. . . . We should be able also to stand above morality-and not only to stand with anxious stiffness of a man who is afraid of slipping and falling any moment, but also to float above it and play. How then could we possibly dispense with art-and with the fool?" (Nietzsche 1974, p. 164). Calling for a "lighter," freer individuality, comfortable with all of its disguises and multiplicity, Nietzsche gave ultimate priority to the uninhibited foreground of life (i.e., playful dissimulation and festival) over rational culture (Nietzsche 1982b, p. 683; also 1974, p. 38).

Although ultimately subordinate to aesthetics, the "will to truthfulness" still has an important place. Nietzsche stated, "This will to mere appearance, to simplification, to masks, to cloaks . . . to the surface . . . is countered by that sublime inclination of the seeker after knowledge who insists on profundity, multiplicity, and thoroughness, with a will which is a kind of cruelty of the intellectual conscience and taste" (Nietzsche 1966, pp. 160-61). More than ever, Nietzsche believed, the time calls for a will to truthfulness strong enough to endure seeing "real-

${ }^{13}$ Nietzsche implied a pragmatic, rather than a representational theory of scientific knowledge. For example, he spoke about expanding the purview of mathematized science, "not in the faith that this will lead us to know things but in order to determine our human relation to things" (Nietzsche 1974, p. 215). 
ity as it is," in all its multiplicity, chaotic uncertainty, and harshness, whatever the costs. This is the heart of his "immoralism" and "suspicion." Shortly before going mad, he stated, "How much truth does a spirit endure, how much truth does it dare? More and more that became for me the real measure of value" (Nietzsche 1969a, pp. 218, 327-31). The sovereign individual's inclinations for "Dionysian" abandonment and stoical "responsibility" are at "war," but passionate vision and disciplined truthfulness are both needed to face "open seas" and great tasks.

\section{After Modernity: The Permanent Cultural War}

Politics will have merged entirely with a war of spirits; all power structures of the old society will have been exploded. (Nietzsche, Ecce Homo)

Nietzsche viewed his own era to be parallel to Socrates' time; that is, a period of cultural disintegration ripe for epochal rupture (Nietzsche 1974, pp. 303-4). Imagine a sporting, intellectual, or artistic pursuit without standards to judge good from bad performance, rank different performers, and distinguish genuine innovation and creativity from simulation and fraud. Nietzsche argued that just such an evaporation of legitimate authority is already the case in mass culture, politics, and most other important areas of public life. In his view, the tendency of modern theorists to abstractly harmonize irresolvable contradictions and conjure up societal consensus made matters worse. Since all serious cultural achievement demands stretching, striving, and struggling, the only way out of the crisis is to restore the matrix for creative individuality and cultural vitality-"strong opponents," resistances, and genuine differences (e.g., Nietzsche 1968b, p. 197).

In a famous passage, Nietzsche called on people to "live dangerously," to wage "war" with their "peers and themselves." But he envisioned war being transformed into a "search for knowledge" and fought over "ideas and their consequences" (Nietzsche 1974, p. 228). By contrast to the nationalist emphasis on the primacy of political power, he argued for subordinating politics to culture. Nietzsche believed that genuine cultural selection is a generative force in all epochs, but, as with Socratic culture, its productive potential is blunted by the herd type of social selection and its consequent political suppression of creative individuals, ideas, and modes of life. Conversely, he imagined a post-Socratic epoch where unconstrained cultural selection would be the hegemonic logic of sociocultural production and reproduction. Rather than regimentation and coercion, cultural leaders and goods would achieve dominance by virtue of their "superiority" in open cultural competition and, thus, ultimately, by their contribution to "ascending life." The new cultural complex 
would intensify, rather than suppress, clashes between strongly held values, vital lived experiences, and creative personalities. This requires institutional spheres that facilitate conflictive perspectives and unparalleled levels of freedom of inquiry, taste, and lifestyle. Permanent war between divergent exemplars, ideas, norms, values, and worldviews means that the culture complex would itself be continually open to contestation and reconstruction (Nietzsche 1968b, pp. 81-82, 346, 395-96; 1968a, pp. 21-27, 44; 1969a, 231-33; Kaufmann 1974, pp. 386-89).

Nietzsche's conceptions of post-Socratic individuality and cultural selection constitute an ethos for cultural leadership and domination. Only sovereign types have the required strength, creativity, and lack of inhibitions to be full participants in the cultural war and to create new ultimate values. Nietzsche conceived of the new order as a "foundation or scaffolding" for this "higher" type of being and task, not as a means to achieve universal freedom and equality. In his view, egalitarian ideals serve cultural mediocrity and mass discipline. Although Nietzsche's antidemocratic polemics were aimed primarily against moralizing, leveling, and regimenting forces that weaken individuality, his elitism still has highly ambiguous elements. For example, he spoke of the "highest men" living "beyond" all rulers and social bonds and of the possible case of a single individual justifying a "whole millennia." It is easy to see how such ideas could be perverted by the types of tyrants he feared were on the horizon (Nietzsche 1968b, pp. 162, 197, 518-19; 1966, pp. 174-77, 201-2; 1969b, pp. 25-26).

Yet Nietzsche held that weak, timid individuals-not the strong-fear difference, "love harsh judgments," and are predisposed to violence. By contrast, he thought that sovereign types, imbued with perspectivism and an aristocratic (cultural) warrior ethic, would oppose regimentation: "reproaching, punishing, and attempt[ing] to improve others" (Nietzsche $1982 a$, pp. 139,$175 ; 1974$, pp. $232-33,254)$. In his view, the challenge of the age is to nurture new cultural leadership capable of resisting rampant demagoguery, chauvinism, toadyism, and coercion. Nietzsche wanted a cultural complex that would escape later modernity's excessive moralism, inwardness, intolerance, and the all-pervasive concern with control. $\mathrm{He}$ believed that genuine difference or particularity, taken seriously, would favor more free, natural, and plural ways of life.

Nietzsche's prescriptions that life ought to be an "experiment of the seeker of knowledge . . . not a duty, not a calamity, not trickery" and that society ought to be an "experiment" and "not a "contract"" are telling (Nietzsche 1974, p. 255; 1969c, p. 229). Sharing the faith of radical democratic thinkers he opposed, he said yes to human nature and no to "foundations." His declaration that "man" must be "overcome," recently echoed by Foucault, calls for an end of the subject and an "unin- 
hibited, a very uninhibited hand" (Nietzsche 1969b, p. 159). But his normative appeal to a potential stratum of individuals capable of bringing the new cultural epoch into being the day after tomorrow is problematic. Other than creativity, diversity, and self-mastery, post-Socratic values are an open question left to aesthetic sensibilities and vitalistic forces. From his perspective, however, the charge that ethical foundations are lacking is a moralistic reflex of the moribund Socratic subject; its flickering desire for security must be expunged. Inverting Plato's allegory of the cave, Nietzsche $(1974$, p. 167) declared, "After Buddha was dead, his shadow was still shown for centuries in a cave-a tremendous, gruesome shadow. God is dead; but given the way of men, there may be caves for thousands of years in which his shadow will be shown.-And we-we still have to vanquish his shadow, too."

\section{NIETZSCHEANISMS: NIETZSCHE'S ANTISOCIOLOGY AND SOCIAL THEORY}

I am a Doppelgänger, I have a "second" face in addition to the first. And perhaps also a third. (Nietzsche, Ecce Homo)

Numerous and varied indirect appropriations preclude an inclusive mapping of Nietzsche's impact on social theory. However, three important currents can be identified. First, certain modern theorists employ his ideas to moderate exaggerated claims about rationality, science, social consensus, and progress within their own tradition. Although they express ambivalence about modern society, they reject Nietzsche's arguments about cultural exhaustion and attempt to strengthen modern theory by making it more reflexive. Another group of appropriators, on the left, sense a depletion of resources for progressive reform or revolution. They aim to go beyond modern theory and create new approaches that resuscitate emancipatory hopes or individual or sociocultural particularity. Because they do not entirely sever their ties to emancipatory theory, these positions remain at the border of modern theory, even when they are intended as postmodern departures from it. A third type of appropriation calls for a revolution from the radical right. These positions break sharply with modern theory, subordinating individuality to remythologized ideas of culture, nation, and state.

\section{Nietzsche and Modern Social Theory}

Weber and Durkheim are usually treated as the most important founders in the sociological canon. Weber was the leading figure among a generation of German thinkers influenced by Nietzsche. Conversely, Durkheim is the leading representative of the type of French sociologism that 
Nietzsche decried and belongs to a long line of thinkers engaged and criticized by new cultural theory. Discussion of the two thinkers will help draw out Nietzsche's challenge within modern theory.

Nietzschean ideas pervade Weber's corpus, even though they are mostly implicit and hard to isolate ${ }^{14}$ For example, qualifying his idealtypes, he held that in "the great majority of cases actual action goes on in a state of inarticulate half consciousness or actual unconsciousness of its subjective meaning" (Weber [1921] 1968, p. 21). He stressed the important role irrationality plays in social life and implied that most persons cannot face the uncertainty and complexity inhering in a world of "irreconcilably antagonistic values." Only stronger individuals have the personal resources to cope with the full implications of the "warring gods" and ultimate meaninglessness of history and to take responsibility for creating their own meaning (Weber [1904-17] 1949, p. 18; [1919] 1958c). Like Nietzsche, Weber stressed the centrality of cultural analysis, selection, and elites, the importance of local, individual, and regional particularities, and the towering threats posed by mass discipline, domination, and rationalization. Also, he warned about welfare institutions making people passive objects of control, socialism recreating a more repressive version of ancient Egypt or China, and instrumentalities leveling genuine culture. ${ }^{15}$ Weber came to these positions by his own path, but his arrival was facilitated by Nietzschean ideas and the broader agenda they set for social theory (e.g., Baier 1981-82; Hennis 1988, pp. 158-61).

Nietzschean themes appear in Weber's critiques of crude representational thinking, especially as manifested in the tendency to mistake heuristic devices for reality. He spoke of the hairline between "science" and "faith," and took a perspectivist position toward knowledge in his highly qualified defense of "objectivity." For Weber, the values that make science "worthwhile," define its "problems," give it "direction," and generate "belief" in its efficacy originate outside its borders in life's "irrational reality." He held that modern science must be grasped in light of Western culture's "optimistic faith" in rationality, which he

${ }^{14}$ On Weber and Nietzsche, see e.g., Fleischmann (1964), Turner (1982), Kent (1983), Eden (1983, 1987), Schroeder (1987), Hennis (1987; 1988, pp. 146-62), Bloom (1988, pp. 194-240), Goldman (1988, 1992), Liebersohn (1988), Mommsen (1974, 1989), Scaff (1989), Strong (1992), Warren (1992).

${ }^{15}$ For example, after singing praises to unadorned life in Oklahoma Territory, Weber (quoted in M. Weber [1926] 1975, p. 293) stated: "Too bad; in a year this place will look like Oklahoma [City], that is, like any other American city. With almost lightening speed everything that stands in the way of capitalistic culture is being crushed." The same powerful sentiments appear at the end of the Protestant Ethic (Weber [1904] 1958a, pp. 181-83). 
considered deeply "problematic" (Weber 1949, pp. 71-112). He attacked positivist claims about self-grounding science and conjuring up the ideal out of the real. After "Nietzsche's devastating criticism of those 'last men' who 'invented happiness," Weber argued (1958c, pp. 143, 148), how can anyone believe the "big children" who still see science as a "way to happiness" and to escape decision?" ${ }^{16}$ Like Nietzsche, he called for a modest version of science that, by coming to terms with its limits, faces realities without moralizing illusions. Compare Nietzsche's (e.g., 1966, pp. 49-50; 1969a, pp. 218, 312, 328-31) views about living "without illusions," enduring "disagreeable truths," and being "strong enough" to conceive "reality as it is" to Marianne Weber's (1975, pp. 662-63, 681-84) comments on her husband's heroic "realism" or "illusion-free illumination of the various roots of existence" (see also Weber $1958 b ; 1958 c)$.

But remaining in the orbit of modern theory, Weber diverged from Nietzsche on many issues. For example, Weber rejected his view of ressentiment as a general source of religious ethics. Like Nietzsche, Weber detailed the awesome homogenizing power of modern rationalization and even traced its ultimate roots to Western antiquity and early Christianity. But Weber also held that rationalization sharpens the differences between the various spheres of life and value and that it produces unparalleled space for autonomous individuality. It is significant that he found highly aestheticized culture repellent and feared its sociopolitical consequences. ${ }^{17}$ Compare Nietzsche's positions about the primacy of art to "unmusical" Weber's (1958a, pp. 155-56) appeal to stronger individuals to set to work, understanding that disenchantment has permanently driven the sublime out of all but their most intimate circles. Additionally, Weber's "realism" about political elites and power contradicts Nietzsche's hopes about post-Socratic cultural selection and substantively legitimate authority. Weber was no Nietzschean, but he selectively deployed Nietzsche's ideas to challenge modern theorists to recognize the limits of rationality and rethink their practices accordingly. He ultimately affirmed sociology, the normative potentialities of modernity (e.g., "responsibility"), and liberal institutions, but he was still highly ambivalent

${ }^{16}$ See Stephen A. Kent (1983) on Parsons's exclusion of Weber's reference to Nietzsche's "last men" just before the famous passage about "specialists without spirit, sensualists without heart" in the English translation of the Protestant Ethic. Kent shows how subtle Nietzschean themes can be overlooked.

${ }^{17}$ See Marianne Weber's (1975, pp. 318-19, 372-80, 455-64) account of her spouse's reaction to the Nietzschean poet Stefan George and Freudo-Nietzscheanism of Otto Gross. 
about the prospects of democracy. ${ }^{18}$ In modern theory, Nietzschean ideas are often entwined with somber or tragic visions about modernity and with pessimistic views about the possibility for stronger democracy. ${ }^{19}$

Although Durkheim warned vigorously about anomie, social inequality, expansive state power, and the erroneous equation of material with social progress, he still implied that rational culture develops progressively and provides fresh resources for coping with crises. In particular, he argued that norms and values affirming the individual's "personal dignity" are growing stronger, more exact, and more "universal." Because complex interdependence depends on individuals freely gravitating to roles consistent with their native ability, it calls forth increased emphasis on individual rights and equal opportunity. Moreover, modern culture has much greater "autonomy" from its material "substrata" and much enhanced capacities for rational representation. Ideas and values can be signified more clearly to larger numbers of people than ever before (see e.g., Durkheim [1893] 1964, pp. 171-73, 287-91, 321, 345, 329-50, 38188; [1912] 1965, pp. 479-96; [1924] 1953, pp. 23-34; [1898] 1973a; [1925] 1973b, pp. 1-14, 114-16, 265, 277-81). Like Nietzsche, Durkheim spoke of a "spiritualization" of culture. But he celebrated precisely what Nietzsche attacked, arguing that learning "to think and act with concepts" liberates people from the "yoke of the organism" (i.e., "passion" and "senses"), putting them under the regulation of higher "social causes." ${ }^{20}$ In Durkheim's view, cultural rationalization enhances potentialities for individual autonomy, social diversity, and "less imperative" social control (Durkheim 1964, pp. 287-91, 299, 302, 321, 333, 345-46, 349; 1965, pp. 307-8, 481-82; 1973b, pp. 95-126).

${ }^{18}$ While arguing that Weber's "liberal notion" of society "qualified" his view of Nietzsche, Mommsen (1988, pp. 172-75; 1974, pp. 382-453) still claims that Weber's ambivalence about democracy opened the way for Carl Schmitt's protofascist appropriation.

${ }^{19}$ Daniel Bell's Cultural Contradictions of Capitalism provides a good example of contemporary modern theory with a strong Nietzschean flavor. While opposing Nietzschean sensibilities, Bell gives primacy to culture, criticizes degraded cultural standards (i.e., the "eclipse of distance"), and attacks a cultural leadership that exerts hegemony through radical democratic ideology ("adversary culture"). Bell (1978, p. xxix) stated that "we stand, I believe, with a clearing ahead of us. The exhaustion of Modernism, the aridity of Communist life, the tedium of the unrestrained self, and the meaninglessness of monolithic political chants, all indicate that a long era is coming to a slow close." Bell's quasi-Nietzschean argument is reminiscent of Foucault's (1989, p. 327) point about his own "anti-Nietzschean theses" being "nevertheless Nietzschean."

${ }^{20}$ The genders, however, do not fare equally in this process. Durkheim held that women, having less developed brains, are more emotional and less capable of abstract thinking (the resulting gender division of labor supposedly facilitates conjugal solidarity; e.g., Durkheim 1964, pp. 54-63; [1897] 1966, pp. 166, 215-16, 270-74, 341-42, 385-86; Roth 1989-90; Lehmann 1991, 1993, 1994). 
Durkheim favored increasing moral regulation of the "body" to stem uncontrolled desire and to halt the dissipation of morality and democracy. Like Nietzsche, he saw priestly asceticism as "an integral part of all human culture," but he viewed it very affirmatively, imploring that "moral" life (i.e., "real living") be given primacy over "art" ("a game"). "We must see people as they are," he argued, in "their ugliness and wretchedness-if we want to help them. Art faces the other way" (Durkheim 1965, pp. 307-8; 1973, pp. 271-73). Durkheim wanted to employ science and moral education to discipline aesthetic impulses and tie the individual's "whole being" to society. He believed that increased moral regulation was needed to avert social disintegration and an authoritarian state. However, his unhesitant, celebratory tone about the "hyperspirituality," "great voice," "great collective ends," "liberating dependence," "infinitely richer and higher reality" and "love" of the "social" directly contradicts Nietzsche's "uninhibited hand" (Durkheim 1964, pp. 51-53, 239-40, 287-91, 329-50; 1966, pp. 246-57; 1965, pp. $355-56,481-96 ; 1953$, pp. $23-34,54-59,72,84-85 ; 1973 b$, pp. 39 , $72-75,100-102,251,271-77)$.

While these brief comments on Durkheim are necessarily one-sided, they illustrate tendencies of modern theory that come under attack by Nietzschean antisociology. From this vantage point, Durkheim erases the body, elevates Socratic conceptualism into a normative ideal, and legitimates the nascent welfare state's control mechanisms. Given Durkheim's active role in the Third Republic, it is not surprising that younger Bergsonians and Nietzscheans considered him to be the scourge of the regime's alleged joyless rationalization and regimentation (Hughes 1977, pp. 336-91; Lepenies 1988, pp. 47-90). More nuanced modern positions by recent theorists, from Talcott Parsons to Jürgen Habermas, moderate Durkheim's moralizing inclinations but maintain similar links between cultural rationalization, representation, autonomous individuality, and democracy. New cultural theorists charge that these quasi-evolutionary visions of progressive cultural rationalization reflect the theorists' own values, obscure cultural exhaustion, and, ultimately, justify liquidation of particularity.

\section{Nietzscheanism on the Cultural Left and Postmodern Divide}

The cultural left has employed Nietzschean ideas in diverse critiques of modern theory. For example, the radical socialist Kurt Eisner used them to attack orthodox Marxism; Otto Gross linked them to Freud, expressionism, and matriarchal communism; and Helen Stöcker employed them in radical feminism (see Thomas 1986, pp. 17-25, 80-95; Taylor 1990, pp. 89-116). Randolph Bourne's ([1917] 1964) sharp Nietzschean attack 
on his teacher, John Dewey, is illustrative. He felt that his mentor's support for the United States' entry into World War I was a capitulation to the power system following from his instrumentalism and lack of aesthetic "vision." Conversely, Bourne saw Nietzsche as a hammer against repressive rationalization. Marianne Weber (1975, pp. 319, 455-64) describes similar tensions between her spouse and the Nietzschean poet Stefan George and his avant-garde circle. Like Dewey and Bourne, the split was over rational culture and the war. Nietzsche's passionate emphasis on aesthetically overcoming bourgeois life had strong appeal for those seeking radical alternatives, during culturally pessimistic times (Thomas 1986, pp. 96-111; Peukert 1992, pp. 86-106; Aschheim 1992, pp. 71-76).

On the cultural left, Nietzschean ideas are found in heterodox fusions. For example, Bourne ([1914] 1981, p. 238) described his "paradoxical desire for Tolstoyan ends through Nietzschean means; socialism, dynamic social religion through the ruthless application of scientific materialism." In the 1930s, French ultra-leftist, Georges Bataille, fused Nietzsche with Marx, de Sade, Freud, and Durkheim. Celebrating the "heterogeneous," this antibourgeois aesthete explored extreme experiences and forbidden behaviors, including violence. Nietzsche and Marx both appear in Ernst Bloch's redemptive revolutionism and quasireligious philosophy of hope (Bataille 1985, 1992; Habermas 1987a, pp. 212-21; Aschheim 1992, pp. 182-84, 229-30, 286-95). Nietzschean ideas helped Max Horkheimer and Theodor Adorno ([1944] 1972, p. 44) shift the focus of their critique from capitalism to Western rationality. They held that new capacities for imposing terror, deflecting criticism, and regimenting workers (i.e., Stalinism, fascism, corporate capitalism) are rooted deeply in Western civilization and require a fundamental cultural critique. Herbert Marcuse spoke of global convergence toward "onedimensional," "advanced industrial society," which manipulates needs so effectively that "negativity" and "opposition" are eliminated. Applauding Nietzsche's attack on the repression of pleasure and ecstatic experience, he held that "artistic alienation" offers a "remembrance of freedom in the totality of oppression." If rationalization has become a singular logic of domination, the Enlightenment project of emancipation and progress and modern theory must be radically rethought. For this reason, the cultural left gravitated to Nietzsche (Marcuse [1945] 1993, pp. 180,$195 ; 1964 ; 1966$, pp. 119-24, 232).

Rising to popularity in the wake of May 1968 radicalism and weakened Marxism, French poststructuralists engaged a diverse lineage, including Descartes, Kant, Comte, Durkheim, Marx, Husserl, Bataille, Bachelard, Saussure, Heidegger, Lévinas, Sartre, Lévi-Strauss, and Althusser. But Nietzsche has special prominence in this tradition. For example, Fou- 
cault proclaimed his "fundamental Nietzscheanism," which is easy to detect in his inquiries about the human sciences and discipline. Although his analyses of "homogenization" and "normalization" have sociological facets, his positions on the body, power/knowledge, perspectivism, subject, and difference give his work a distinct Nietzschean tone. Foucault explored connections between Western morality, rationality, and domination, exposing disciplinary forces operating in spheres and practices generally presumed to serve human needs. Like Nietzsche, he held that discipline has been radically diffused, during the last two centuries. The new "micro-physics" of power reduces reliance on visible, centralized violent force, substituting a vast array of microscopic disciplinary mechanisms and much more sweeping controls over the body. In his view, normative languages of solidarity and interdependence tame the body and serve the new system of "micro powers." In Nietzschean fashion, he embraced an "aesthetics of existence," stressing individuals artfully shaping their lives and appreciating diversity (Foucault 1973, p. 342; 1979; 1989, pp. 249, 311, 325-30; 1984; 1990; Ferry and Renaut 1990, pp. 119-21; Best and Kellner 1991, pp. 34-75; Miller 1993).

Jacques Derrida (1976, p. 19) acknowledges Nietzsche's substantial contribution to his own views about liberating the "signifier" from "truth or the primary signified" and decomposing the subject/object and appearance/reality dualisms into a centerless, relational web of signifiers governed by the free "play of differences." Like Nietzsche, he stresses the centrality of language in cultural domination, and his ideas of textuality and differance are opposed to the workings of this process. Derrida's moves subvert modern theory's presuppositions about representation, communication, and social integration. With Foucault, moreover, he criticizes sociological conceptions of concentrated, macroscopic power, arguing that they ignore pervasive disciplinary forces operating as "decentralized and heterogeneous microphenomena." He states "that one must start, as Nietzsche doubtless did, from difference in order to accede to force and not vice versa." In Nietzschean style, Derridean deconstruction attacks cultural homogenization and celebrates particularity (Derrida 1981, 1982; 1988, p. 149; Berman 1988, pp. 199-222).

Nietzschean ideas about language and homogenization also appear in Jean Baudrillard's grim vision of total semiotic control. In his view, television, computers, and other innovations in information and image production reconstitute cultural experience cybernetically. Today's hyperreality is an all-encompassing whirl of aleatory signifiers, a completely one-dimensional plane that neutralizes all modes of distancing oneself from the immediacy of cultural experience. Critique merely shores up the failing reality principle (i.e., the illusion that realities underlie appearances and signifiers have referents). Even art loses its critical negativity. 
Ubiquitous "simulation" dissolves the social, power, politics, subjectivity, and history. Calling for a total break with modern theory, Baudrillard holds that accepting culture as only surface (i.e., approaching it with "indifference," "fascination," and receptivity to "seduction") is the only escape route from the current phase of total cultural domination (Baudrillard 1983a, 1983b, 1987, 1990).

In broader postmodern currents of new cultural theory, Nietzsche is often mentioned as an ally and precursor. ${ }^{21}$ Nietzschean themes are pervasive; postmodernists usually favor innovative, fractal, discordant, aesthetic styles of expression over conventional representation, perspectivist over objectivist theories of knowledge, and nonrational over rational visions of culture. Nietzschean motifs are prominent in their arguments about the role of language in cultural domination, critiques of the therapeutic state, affirmations of multicultural differences, and claims about problematic presuppositions, unexplored areas, and marginalized voices in modern theory. Also, their playful attacks on moralistic ideologies, positivism, parochial cultural biases, and intellectual canons have a Nietzschean thrust.

Because the cultural left does not completely cut its ties to emancipatory strains of modern theory, its adherents diverge from Nietzsche in important respects. For example, even in the Frankfurt school's most pessimistic phase, concepts such as "negative dialectics," and "total administration," or theory as a Flaschenpost (message in a bottle) had traces of their Marxian roots. Poststructuralists and postmodernists reject emancipatory theory outright, but their visions of radically egalitarian heterotopias are hardly Nietzschean. In particular, their semiotic attacks on the hierarchical facets of language manifest a muted version of the egalitarian, pluralist thread of left-leaning modern theory. Moreover, these thinkers sometimes express an extreme relativism, epitomizing what Nietzsche considered to be the "nuthouse" of liberal modernism. Generally, poststructuralists and postmodernists ignore Nietzsche's ideas about restoring authority, hierarchy, and cultural domination under a new rank order of values and leadership. They embrace his Dionysian side apart from his affirmations of severity of spirit, self-discipline, and science. Leaving sovereign individuality behind, these positions sometimes dissolve persons into an aleatory play of signifiers and desires. For example, the individual disappears completely in Baudrillard's vortex of signs. His points about resisting semiotic control through "hyperconformist simulation" or utter "indifference" and returning to ritual and myth suggest a much more ambiguous future than Nietzsche's post-Socratic

${ }^{21}$ See Gooding-Williams (1987), Strong (1988, pp. 310-18), Berman (1988), Koelb (1990), Shrift (1990), and Owen (1992, pp. 133-34) on Nietzsche and postmodernism. 
scenario. One-sided aestheticism and amoral fascination blur differences between right and left.

\section{Radical Right Nietzscheanism}

The political directions of Nietzscheanism's highly aestheticized antibourgeois, antidemocratic, and irrationalist themes are highly ambiguous and pliable. Georges Sorel employed them in arguments about the purifying powers of violence, war, and mass mobilization (he can be considered a precursor to both communist and fascist ideology); Italian futurists used them in their nationalist aesthetic of technology and violence; Ludwig Klages fused them with myth, anti-individualism, and anti-Semitism; the German youth movement integrated them into a völkisch conception of national cultural renewal; and Rudolf Laban applied them in ecstatic dance forms presented first in avant-garde Ascona and later to serve the Nazi regime (Aschheim 1992, pp. 51-84, 133; Hughes 1977, pp. 161-82, 339-40). During World War I, Scheler, Sombart, and others invoked Nietzsche to glorify German nationalism (e.g., Staude 1967, pp. 63-94; Thomas 1986, pp. 96-111; Aschheim 1992, pp. 113-17, 144-48, 153). After the war, as Aschheim holds, the "mythologized Germanic Nietzsche" became the most important source of inspiration, vision, and intellectual legitimation for the resurgent radical right (pp. 153-63; Herf 1986).

Nietzschean themes pervaded Ernst Jünger's masculinist celebration of the community of the trenches, expressing magical fascination with the beauty of war, violence, pain, and death. He deplored bourgeois democracy's "feminine" egalitarianism, welfare provisions, and sacrifice of adventure for security. Imagining collective transcendence of bourgeois mediocrity, he portrayed workers being forged into a technocratic apparatus and acting unhesitatingly together in service of higher cultural goals. His enchanted protofascist vision justified mass regimentation on its own immanent aesthetic bases. According to Jünger, persons overcome bourgeois estrangement by giving up their individuality and participating in a recovery of national cultural particularity (Jünger [1931] 1993; Huyssen 1993; Sokel 1993; Zimmerman 1990, pp. 46-65).

Heidegger illustrates the ambiguity and the fluid borders of Nietzscheanism. Many facets of his work anticipate postmodern positions. French poststructuralists came to Nietzsche through his writings, and Heideggarian themes abound in their work. It is possible to. evaluate aspects of Heidegger's philosophy and social theory apart from his politics and fuse them to positions with entirely different sociopolitical directions. Yet, even when his complicity with the Nazi regime is put aside, the protofascist themes in his work are still very strong. Like Jünger, 
Heidegger collectivized Nietzsche, albeit in an antitechnological vision of the Volk. Praising Nietzsche as the most advanced thinker of the era, Heidegger transforms sovereign individuality à la Jünger. He saw the Übermensch as neither individual nor mass, but as a "type" of the "same coinage," prefigured in "Prussian soldiery and the Jesuit order." In the same text Heidegger (1991a, pp. 99-100) embraced Nietzsche's "masculine aesthetics," implying that it embraces yet points beyond Wagner's "collective artwork"; that is, which "should be a celebration of the national community" and "the religion." Such aesthetics have "redemptive" power, generating a "pure state of feeling" that lifts the individual out of his or her prosaic existence (see also Heidegger 1991b, pp. 77-91; Zimmerman 1990, pp. 34-112).

Hans Freyer's widely read Revolution from the Right (1931) argued that the working class is thoroughly integrated into "industrial society," making genuine revolution from the left impossible. Breaking with "reactionary" conservatives as well as with the left, he called for a new right that would unite the nation across class lines and assert the collective identity and interests of the Volk (Muller 1987). Freyer, and others on the radical right, wanted an entirely new type of culture and society. Like Nietzsche, they saw liberalism, socialism, and all democratic ideologies to be part of a universal process of instrumental rationalization that steamrolls everything in its path and produces everywhere lifeless, joyless, economistic, homogenized mediocrity. On a global scale, the lure of "good plumbing," material interest, security, and faceless administration levels culture and produces weak, interchangeable, nihilistic people. The far right argued, however, that the German nation had not yet completely lost its original essence, vitality, and particularity (i.e., Volksgeist or cultural totality). But the legacy is gravely threatened by corrosive rationalization, spreading outward, like an infectious disease, from imperialistic centers where such leveling is already completely victorious (i.e., England, the United States, and Russia). ${ }^{22}$

The radical right envisioned a Middle European, sociopolitical regime unified by the recovery of the German nation's distinctive mythic, vitalist, intuitive, pagan cultural roots. This move aimed to break with Christianity's universal logic of rationalization and homogenization. But the radical right also called for Raum to preserve and cultivate the heritage of the Volk. The cultural survival of spatially dispersed Germanspeaking people depended on their being fused into a singular political will capable of creating a strong state with sufficient territory. Major

${ }^{22}$ Hans Freyer's former doctoral student, Ernest Manheim, has provided very helpful insights in this section (interviews with David Smith and myself, May 23 and June 2, 1994). 
theorists of the radical right saw Nazism merely as the start of a much more profound cultural awakening of the Volk. Usually they avoided direct participation in the movement or distanced themselves from it after initial involvement. While they contributed significantly to the climate that produced Nazism, their positions appear to be relatively independent of its explicit politics. The consequent ambiguity opens their thought to diverse fusions, even with approaches on the cultural left. However, many lesser thinkers, following in their tracks, made Nietzsche into a totem of the regime; even Hitler paid homage in an official visit to the Nietzsche archives (Bäumler 1931; Muller 1987; Lepenies 1988, pp. 334-49; Aschheim 1992, pp. 232-314).

Allan Bloom (1988, p. 222), argued that "today virtually every Nietzschean . . . is a leftist," but his own Nietzschean themes contradict this claim. More important, radical right Nietszcheanism is resurgent in Europe. For example, Jünger is once again a widely read and honored figure. His work has a very contemporary texture and is seen as being precursosry to postmodernist representation (Sokel 1993). There is also a renaissance of radical right interest in Heidegger, Klages, and Carl Schmitt. And, as they did in Weimar, radical right reading groups and clubs have proliferated again. Writers such as Günther Maschke, Heiner Müller, Armin Mohler, Aleksandr Dugin, and Alain de Benoist revive the distinction between culture and civilization, virulent antagonism to bourgeois mediocrity, and idea of a revolution from the right. Some of these thinkers appropriate poststructuralist themes and make other adjustments aimed at reaching wider audiences. ${ }^{23}$ The sociopolitical climate-arising from neoliberal "shock-therapy," erosion of social democracy, pervasive conflicts over ethnicity, religion, and immigration, and seeming obsolescence of postwar ideologies-provides grist for radical right critiques of capitalism and democracy (Habermas 1989; Aschheim 1992, pp. 306-7; Huyssen 1993; Neaman 1993; Dahl 1994). ${ }^{24}$

${ }^{23}$ See Piccone (1993-94) and Benoist (1993-94) for very interesting discussion of positions of the French new right. The entire issue of $T$ elos (no. 98/99), where these articles appear, deals with the convergence of positions on the new right and cultural left. Antiliberal, antibourgeois, antiuniversalist, antiegalitarian, and anti-individualist themes are fused with perspectives that oppose cultural homogenization and champion the recovery of cultural particularity. Thinkers like Benoist attempt to build bridges to the left, taking up themes of cultural diversity and difference and emphasizing the defense of local culture against instrumentalism and American capitalism. These approaches share features with the new right of the Weimar era, including ambiguity about the politics and structure of the new regimes.

${ }^{24}$ Conversations with Göran Dahl were very helpful in this section. Also, conservative German "antisociologists" (i.e., Helmut Schelsky, Friedrich Tenbruck, and Arnold Gehlen) express Nietzschean themes that deserve attention. But their positions and relation to the right require a lengthy inquiry and discussion that cannot be completed here. 
The radical right embraces Nietzsche's scathing attacks on decadent liberalism, socialism, and democracy, his idea of post-Christian, European culture, and his aestheticism, elitism, vitalism, and masculinist metaphors. They see him as their precursor and even interpret their departure from his individualism to be a necessary Nietzschean step, shattering liberal decadence and purposelessness. However, radical right statism, regimentation, and anti-Semitism are all profoundly contradictory to Nietzsche's views. Racist national mythology and authoritarian politics clash directly with his antimoralist perspectivism and antinationalist affirmation of the mixing of peoples and cultures. The radical right's vision of the future bears no resemblance to his pluralistic ideals of cultural selection and post-Socratic culture. The radical right aims to liquidate individual particularity in order to preserve the particularity of a mythologized, national-cultural totality. Nietzsche implied that this move was already latent in his day; it manifests the new tyranny he saw arising in the twilight of Socratic culture.

\section{AFTER NIETZSCHE: A RETURN TO HISTORY?}

That life is in need of the services of history, however, must be grasped as firmly as must the proposition ... that an excess of history is harmful to the living. (Nietzsche, Untimely Meditations)

Nietzsche's absence from sociology diminishes disciplinary resources for fully engaging some of the most important classical and contemporary social theories. Moreover, his antisociology opposes tendencies to overvalue rationalization, overestimate levels of consensus and integration, and mistake domination and coercion for social integration or solidarity. It also poses sharp critiques of the social self and mass regimentation. And, his emphasis on the musical, bodily, and nonrational side of interpersonal ties points to gaps in normative and instrumental theories of social bonds. As Maffesoli (1991, p. 19) argues, homo aestheticus ought to be entertained along with homo politicus and homo economicus. Nietzsche's affirmation of conflictive points of view and multiperspectival theoretical fields points to the limits of "general theories" that arrogate all reality and integrated theories that abstractly harmonize irreconcilable differences. Finally, his relentless critique of ethical formalism and concern for authenticity addresses the all-too-human side of intellectual life, calling on us to reflect on the meaning of our practices and exercise responsibility.

While social theory can be a fruitful source of empirical hypotheses and problems, its primary value derives from its capacity to clarify, 
criticize, and debate the presuppositions of specialized practices and the broader "world images" in which they are embedded. It raises foundational questions, which are bound up with normative issues and go beyond the empirical scope of strictly "sociological theory." In this regard, Nietzschean thought poses the question of the value of social knowledge in the context of the broader issue of its historical and cultural rootedness. Modern theorists, like Weber and Simmel, who engaged Nietzsche, ultimately rejected the cultural exhaustion thesis, but seriously entertained his charge that sociology employs norms of a decadent epoch as its own standards. In Baier's words, these thinkers became "children of the pathos of distance" (Baier 1981-82, pp. 32-33). The best of the early generation of "Nietzschean" modern theorists shared a critical reflexivity about the foundations of their practices and the unknown horizons of knowledge that were missing in positivism. Modern theory has been enriched by the creative tensions and insights generated by past carriers of Nietzschean "otherness." Reengaging his perspective would also benefit sociological theory today.

Vincent Pecora (1991, pp. 129) portrays Nietzsche as an "indispensible mirror - 'the bad conscience'-of a damaged bourgeois faith in historical reason thrown back on itself." From this vantage point, the current Nietzsche revival is not at all surprising. Nietzschean social theories gained momentum during the contractions of the post-World War II era-the growth and collapse of the period's rosy visions of progressive modernization and harmonious postindustrialism. The new approaches grew more popular during the late 1970s and 1980s when global restructuring of political economies, geopolitics, and communications opened sociocultural and political borders to contestation and weakened the nation-state's capacity to mediate the relationship of capital and community and conflicts over citizenship rights and identity (e.g., esp. relating to minority issues). Nietzschean emphases on cultural homogenization and liquidation of particularity were revived in the face of fresh threats to individuality, subgroup, and locality by new constellations of highly rationalized, powerful, fluid, decentered yet global, collective entities, conditions, and forces. Opposing approaches, such as Foucaultian micropolitics and Habermasian universalism address the same context.

Responding to the severe erosion of social democracy and the welfare state and the trend toward a more minimalist vision of democracy (i.e., free markets, suffrage, and formal legal rights), social theorists once again raise the issue of cultural exhaustion-in Adorno's words, they hold that "culture" no longer contains the "salt of truth." 25 Today, however,

25 "There are no more ideologies in the authentic sense of false consciousness, only advertisements for the world through its duplication and the provocative lie which does not seek belief but commands silence," said Adorno ([1967] 1981, p. 34). Com- 
modern theorists, as well as Nietzscheans, express doubts about the vitality of democratic ideals. ${ }^{26}$ Terry Eagleton (1992, pp. 30-39) holds that pervasive Nietzschean pessimism signifies a "crisis in Western culture"-culture is too fragmented to provide resources for voicing and reconciling societal contradictions. But Luc Ferry (1994, pp. 5-8) charges that Nietzschean deconstruction is itself exhausted, having lost the "ability to negate" or produce "anything new." He calls for a "historicization" of theory and a return to "internal criticism" (i.e., analyzing "societies in the name of their own principles" and their unmet "promises"), which presumes the vitality of democratic culture. These differences between social theorists on the left demonstrate that the legacy of Nietzsche is still contested terrain.

A growing number of social theorists, seeking democratic alternatives to postwar models of communism, social democracy, and liberalism, hold that the question of "radical democracy" must be posed anew. They entertain pluralist and antifoundationalist themes from new cultural theory along with facets of earlier radical democratic theories. ${ }^{27}$ While Nietzsche was no democrat, his antimoralism and his critique of evolutionary historicism are still useful deconstructive tools, pointing to the limits and vulnerabilities of any recovery of history and to the pitfalls of premature celebrations of newfound global interdependence. But Nietzsche himself did not give up entirely on the "historical sense." His normative vision of a pluralistic, experimental, post-Socratic culture was rooted in nascent conditions of his day. This aspect of his thought has not been taken up adequately in the three currents of appropriation discussed above, and it has yet to be explored in the full context of his antisociology.

pare Horkheimer's portrayal of critical theory's earlier optimistic historicism: "Again and again in history, ideas have cast off their swaddling clothes and struck out against the social systems that bore them. ... Thus originates the contradiction between the existent and ideology, a contradiction that spurs all historical progress" (Horkheimer [1947] 1974, p. 178; on Nietzsche and critical theory, see Miller [1978], Pütz [1981-82], Love [1987], Pecora [1991], and Habermas [1982, 1993]).

${ }^{26}$ Modern positions converge with postmodern approaches. For example, Fredric Jameson (1984, 1988), a leading cultural Marxist, holds that postmodernization destroys the cultural bases of ideology critique and all methods that claim to expose realities beneath distorted surfaces. Cultural conservatives, Daniel Bell (1978) and Frances Fukuyama (1992) also point to a postmodern erosion of democratic legitimacy. Even Habermas, the leading critic of postmodernism, holds that the lack of animate democratic norms requires a shift to an "unhistorical" method of critique (Habermas 1979, pp. 96-97; 1987b, pp. 153-97, 332-73, 383; 1987a, pp. 83-105, 339-40).

${ }^{27}$ This tendency is clear in current discussions of pragmatism and the renaissance of interest in John Dewey, whose thought overlaps with Nietzsche at many junctures (e.g., see Dewey [1925] 1988a; [1929] 1988c; [1934] 1989; [1938] 1986; [1939] 1988b). It is noteworthy that Dewey, like Nietzsche, has been left out of the sociological canon. 
An engagement of this vision with the emergent discourse on radical democracy could produce a new Nietzscheanism.

Because sociology was not fully institutionalized until the middle of the post-World War II era, its theories, methods, and, even, readings of the classics are partly-perhaps largely-shaped by the culture of this possibly bygone era. Thus, it is an appropriate time for sociology to entertain a wider range of social theories, including the new visions of radical democracy. Inclusion of Nietzsche among the founders would enhance the discipline's historical sense as it rethinks its foundations and practices at the end of the postwar era. This aspect of his challenge is worth exploring. As he held, the "earthquake reveals new springs" (Nietzsche 1969c, p. 228).

\section{REFERENCES}

Ackermann, Robert John. 1990. Nietzsche: A Frenzied Look. Amherst: University of Massachusetts Press.

Adorno, Theodor W. 1967. Prisms, translated by Samuel Weber and Shierry Weber. Cambridge, Mass.: MIT Press.

Alexander, Jeffrey C., and Steven Seidman. 1990. Culture and Society: Contemporary Debates. New York: Cambridge University Press.

Andler, Charles. 1933. "Nietzsche." Pp. 373-75 in Encyclopedia of Social Science, vol. 11. Edited by Edwin R. A. Seligman and Alvin Johnson. New York: Macmillan.

Andreas-Salomé, Lou. (1894) 1988. Nietzsche, edited and translated by Siegfried Mandel. Redding Ridge, Conn.: Black Swan.

Antonio, Robert J., and Douglas Kellner. 1992. "Metatheorizing Historical Rupture: Classical Theory and Modernity." Pp. 88-106 in Metatheorizing, edited by George Ritzer. Newbury Park, Calif.: Sage.

Aron, Raymond. (1965) 1989. Moin Currents in Sociological Thought, 2 vols. Translated by Richard Howard. New York: Anchor.

Aschheim, Steven E. 1992. The Nietzsche Legacy in Germany, 1890-1990. Berkeley and Los Angeles: University of California Press.

Ashley, David, and David Michael Orenstein. 1985. Sociological Theory: Classical Statements. Boston: Allyn \& Bacon.

Baier, Horst. 1981-82. "Die Gessellschaft-ein langer Schatten des toten Gottes: Friedrich Nietzsche und die Entstehung der Soziologie aus dem Geist der Décadence" and "Diskussion." Nietzsche Studien 10/11:6-33.

Barnes, Harry Elmer, ed. 1948. An Introduction to the History of Sociology. Chicago: University of Chicago Press.

Barnes, Harry Elmer, Howard Becker, and Frances Bennet Becker, eds. 1940. Contemporary Social Theory. New York: Appleton-Century.

Bataille, Georges. 1985. Visions of Excess: Selected Writings, 1927-1939, edited by Allen Stoekl and translated by Carl R. Lovitt and Donald M. Leslie, Jr. Minneapolis: University of Minnesota Press.

- 1992. On Nietzsche, translated by Bruce Boon. New York: Paragon House.

Baudrillard, Jean. 1983a. In the Shadow of the Silent Majorities or, the End of the Social and Other Essays, translated by Paul Foss, Paul Patton, and Philip Beitchman. New York: Semiotext(e).

. 1983b. Simulations, translated by Paul Foss, Paul Patton, and Philip Beitchman. New York: Semiotext(e). 
1987. The Ecstasy of Communication, translated by Bernard Schutze and Caroline Schutze. New York: Semiotext(e).

. 1990. Seduction, translated by Brian Singer. New York: St. Martin's Press. Bäumler, Alfred. 1931. Nietzsche der Philosoph and Politiker. Leipzig: P. Reclam.

Becker, Howard. 1940. "Historical Sociology." Pp. 491-542 in Contemporary Social Theory, edited by Harry Elmer Barnes, Howard Becker, and Frances Bennet Becker. New York: Appleton-Century.

Becker, Howard, and Harry Elmer Barnes. (1938) 1961. Social Thought from Lore to Science, 3 vols. New York: Dover.

Bell, Daniel. 1978. The Cultural Contradictions of Capitalism. New York: Basic Books.

Bendix, Reinhard. 1960. Max Weber: An Intellectual Portrait. Garden City, N.Y.: Doubleday.

Benedict, Ruth. (1934) 1960. Patterns of Culture. New York: Mentor Books.

Benoist, Alain de. 1993-94. "The Idea of Empire." Telos 98/99:81-98.

Berman, Art. 1988. From the New Criticism to Deconstruction: The Reception of Structuralism and Post-Structuralism. Urbana: University of Illinois Press.

Bernard, L. L. 1939. Social Control in Its Sociological Aspects. New York: Macmillan.

1942. An Introduction to Sociology. New York: Thomas Y. Crowell.

Best, Steven, and Douglas Kellner. 1991. Postmodern Theory: Critical Interrogations. London: Macmillan.

Bloom, Allan. 1988. The Closing of the American Mind. New York: Simon \& Schuster.

Bogardus, Emory S. 1948. The Development of Social Thought. New York: Longmans, Green.

Borgatta, Edgar F., and Marie L. Borgatta. 1992. Encyclopedia of Sociology, 4 vols. New York: Macmillan.

Bourne, Randolph. (1914) 1981. The Letters of Randolph Bourne: A Comprehensive Edition, edited by Eric J. Sandeen. Troy, N.Y.: Whitston.

- (1917) 1964. "Twilight of the Idols." Pp. 53-64 in War and the Intellectuals: Essays by Randolph Bourne, 1915-1919, edited by Carl Resek. New York: Harper Torchbooks.

Burgard, Peter J., ed. 1994. Nietzsche and the Feminine. Charlottesville: University Press of Virginia.

Clifford, James. 1988. The Predicament of Culture. Cambridge, Mass.: Harvard University Press.

Collins, Randall, and Michael Makowsky. (1972) 1993. The Discovery of Society. New York: McGraw-Hill.

Cooley, Charles Horton. (1902) 1964. Human Nature and the Social Order: New York: Schocken Books.

Dahl, Göran. 1995. "Will the Other God Fail Again? The Return of the Conservative Revolution in Germany and Russia." Theory, Culture, and Society, in press.

Denzin, Norman K. 1986. "Postmodern Social Theory." Sociological Theory 4: 194-204.

Derrida, Jacques. 1976. Of Grammatology, translated by Gayatri Chakravorty Spivak. Baltimore: Johns Hopkins University Press.

- 1979. Spurs: Nietzsche's Styles, translated by Barbara Harlow. Chicago: University of Chicago Press. Press.

1982. Margins of Philosophy, translated by Alan Bass. Chicago: University of Chicago Press.

- 1988. Limited Inc, translated by Samuel Weber. Evanston, Ill.: Northwestern University Press. 
Dewey, John. (1916) 1985. "On Understanding the Mind of Germany." Pp. 216-33 in 1916-1917, vol. 10 of John Dewey: The Middle Works, 1899-1924. 15 vols. Edited by Jo Ann Boydston. Carbondale: Southern Illinois University Press.

(1925) 1988a. Experience as Nature. Vol. 1 of John Dewey: The Later Works, 1925-1953. 17 vols. Edited by Jo Ann Boydston. Carbondale: Southern Illinois University Press.

- (1929) 1988c. The Quest for Certainty. Vol. 4 of John Dewey: The Later Works, 1925-1953. 17 vols. Edited by Jo Ann Boydston. Carbondale: Southern Illinois University Press.

- (1934) 1989. Art as Experience. Vol. 10 of John Dewey: The Later Works, 1925-1953. 17 vols. Edited by Jo Ann Boydston. Carbondale: Southern Illinois University Press.

- (1938) 1986. Logic: The Theory of Inquiry. Vol. 12 of John Dewey: The Later Works, 1925-1953. 17 vols. Edited by Jo Ann Boydston. Carbondale: Southern Illinois University Press.

- (1939) 1988b. Freedom and Culture. Pp. 63-188 in 1838-1939, vol. 13 of John Dewey: The Later Works, 1925-1953. 17 vols. Edited by Jo Ann Boydston. Carbondale: Southern Illinois University Press.

Durkheim, Émile. (1893) 1964. The Division of Labor in Society, translated by George Simpson. New York: Free Press.

- (1897) 1966. Suicide: A Study in Sociology, translated by John A. Spaulding and George Simpson. New York: Free Press.

- (1898) 1973a. "Individualism and the Intellectuals," translated by Mark Traugott. Pp. 43-57 in Émile Durkheim: On Morality and Society, edited by Robert N. Bellah. Chicago: University of Chicago Press.

- (1912) 1965. The Elementary Forms of Religious Life, translated by Joseph Ward Swain. New York: Free Press.

Cambridge: Polity.

Ill.: Free Press.

- (1925) 1973b. Moral Education: A Study in the Theory and Application of the Sociology of Education, translated by Everette $\mathrm{K}$. Wilson and Herman Schnurer. New York: Free Press.

Dürr, Volker. 1988. "The Young Nietzsche: Historical Philosophizing, Historical Perspectivism, and the National Socialist Past." Pp. 29-40 in Nietzsche: Literature and Values, edited by Volker Dürr, Reinhold Grimm, and Kathy Harms. Madison: University of Wisconsin Press.

Eagleton, Terry. 1992. "The Crisis of Contemporary Culture." New Left Review 196:29-41.

Eden, Robert. 1983. Political Leadership and Nihilism: A Study of Weber and Nietzsche. Tampa: University of South Florida Press.

1 1987. "Weber and Nietzsche: Questioning the Liberation of Social Science from Historicism." Pp. 405-21 in Max Weber and his Contemporaries, edited by Wolfgang J. Mommsen and Jürgen Osterhammel. London: Unwin Hyman.

Farganis, James, ed. 1993. Readings in Social Theory: The Classic Tradition to Postmodernism. New York: McGraw-Hill.

Featherstone, Mike. 1986. "French Social Theory: An Introduction." Theory, Culture and Society 3:1-6.

Ferry, Luc. 1994. "The Three Phases of Modern Philosophy: Tasks for a Secularized Thought." Thesis Eleven 37:1-9.

Ferry, Luc, and Alain Renaut. 1990. French Philosophy of the Sixties: An Essay on Antihumanism, translated by Mary H. S. Cattani. Amherst: University of Massachusetts. 
Fleischmann, Eugène. 1964. "De Weber à Nietzsche." Archives Européennes de Sociologie 5:190-238.

Foucault, Michel. 1973. The Order of Things: An Archeology of the Human Sciences. New York: Vintage Books.

- 1979. Discipline and Punish: The Birth of the Prison, translated by Alan Sheridan. New York: Vintage Books.

Books.

1989. Foucault Live: (Interviews 1966-84), translated by John Johnson and edited by Sylvère Lotringer. New York: Semiotext(e).

—. 1990. "Nietzsche, Freud, and Marx." Pp. 183-200 in Transforming the Hermeneutic Context: From Nietzsche to Nancy, edited by Gayle L. Ormiston and Alan D. Schrift. Albany: State University of New York Press.

Freyer, Hans. 1931. Revolution von rechts. Jena: Eugen Diederichs.

Fukuyama, Francis. 1992. The End of History and the Last Man. New York: Free Press.

Gadamer, Hans-Georg. 1977. Philosophical Hermeneutics, edited and translated by David E. Linge. Berkeley: University of California Press.

Gane, Mike. 1992. "Nietzsche's Imaginary Lovers." Economy and Society 21: 173-91.

Gilman, Sander L., ed. 1987. Conversations with Nietzsche: A Life in the World of His Contemporaries, translated by David J. Parent. New York: Oxford University Press.

Goldman, Harvey. 1988. Max Weber and Thomas Mann: Calling and the Shaping of the Self. Berkeley and Los Angeles: University of California Press.

- 1992. Politics, Death, and the Devil: Self and Power in Max Weber and

Thomas Mann. Berkeley and Los Angeles: University of California Press.

Gooding-Williams, Robert. 1987. "Nietzsche's Pursuit of Modernism." New German Critique 41:95-108.

Graybeal, Jean. 1990. Language of "the Feminine" in Nietzsche. Bloomington: Indiana University Press.

Griswold, Wendy. 1994. Cultures and Societies in a Changing World. Thousand Oaks, Calif.: Pine Forge Press.

Habermas, Jürgen. 1979. Communication and the Evolution of Society, translated by Thomas McCarthy. Boston: Beacon Press.

- 1982. "The Entwinement of Myth and Enlightenment: Re-reading Dialectic of Enlightenment." Telos 26:13-30.

- 1987a. The Philosophical Discourse of Modernity, translated by Frederick Lawrence. Cambridge, Mass.: MIT Press.

1987b. The Theory of Communicative Action Lifeworld and System: A Critique of Functionalist Reason, vol. 2. Translated by Thomas McCarthy. Boston: Beacon Press.

- 1989. The New Conservatism: Cultural Criticism and the Historians' Debate, edited and translated by Shierry Weber Nicholson. Cambridge, Mass.: MIT Press. - 1993. "Notes on the Developmental History of Horkheimer's Work." Theory, Culture and Society 10:60-77.

Hazelrigg, Lawrence E. 1989. Social Science and the Challenge of Relativism, 2 vols. Gainesville: University Press of Florida.

Heidegger, Martin. (1961) 1991a. Nihilism. Vol. 4 of Nietzsche, edited by David Farrell Krell and translated by Joan Stambaugh, David Farrell Krell, and Frank J. Capuzzi. New York: HarperCollins.

. (1961) 1991b. The Will to Power as Knowledge and as Metaphysics. Vol. 3 of Nietzsche, edited by David Farrell Krell and translated by Joan Stambaugh, David Farrell Krell, and Frank J. Capuzzi. New York: HarperCollins. 
Heller, Erich. 1988. The Importance of Nietzsche. Chicago: University of Chicago Press.

Heller, Peter. 1988. "Concerning the Nietzsche Cult and Literary Cults Generally." Pp. 199-218 in Nietzsche: Literature and Values, edited by Volker Dürr, Reinhold Grimm, and Kathy Harms. Madison: University of Wisconsin Press.

Hennis, Wilhelm. 1987. "A Science of Man: Max Weber and the Political Economy of the German Historical School." Pp. 26-58 in Max Weber and His Contemporaries, edited by Wolfgang J. Mommsen and Jürgen Osterhammel. London: Unwin Hyman.

- 1988. Max Weber: Essays in Reconstruction, translated by Keith Tribe. London, England: Allen \& Unwin.

Herf, Jeffrey. 1986. Reactionary Modernism: Technology, Culture, and Politics in Weimar and the Third Reich. New York: Cambridge University Press.

Horkheimer, Max. (1947) 1974. Eclipse of Reason. New York: Seabury Press.

Horkheimer, Max, and Theodor W. Adorno. (1944) 1972. Dialectic of Enlightenment, translated by John Cumming. New York: Seabury Press.

Hughes, H. Stuart. (1958) 1977. Consciousness and Society: The Reorientation of European Social Theory, 1890-1930. New York: Vintage Books.

Huyssen, Andreas. 1993. "Fortifying the Heart-Totally: Ernst Jünger's Armored Texts." New German Critique 59:3-23.

Irigaray, Luce. 1994. Marine Lover of Friedrich Nietzsche. New York: Columbia University Press.

Jameson, Fredric. 1984. "Postmodernism, or the Cultural Logic of Late Capitalism." New Left Review 146:53-92.

. 1988. "Cognitive Mapping." Pp. 347-57 in Marxism and the Interpretation of Culture, edited by Cary Nelson and Larry Grossberg. Urbana: University of Illinois Press.

Jones, Ernest. 1963. The Life and Work of Sigmund Freud, edited and abridged by Lionel Trilling and Steven Marcus. Garden City, N.Y.: Anchor Books.

Jung, C. G. 1961. Memories, Dreams, Reflections, recorded and edited by. Aniela Jaffé, and translated by Richard and Clara Winston. New York: Vintage Books.

. (1921) 1976. Psychological Types, translated by H. G. Baynes. Princeton: Princeton University Press.

- 1988. Nietzsche's Zarathustra: Notes of the Seminar Given in 19341939, 2 vols. Edited by James L. Jarret. Princeton, N.J.: Princeton University Press.

Jünger, Ernst. (1931) 1993. "On Danger." New German Critique 59:22-32.

Kaufmann, Walter. 1974. Nietzsche: Philosopher, Psychologist, Antichrist. Princeton, N.J.: Princeton University Press.

Keesing, Roger M. 1989. "Creating the Past: Custom and Identity in the Contemporary Pacific." Contemporary Pacific 1:19-42.

Kent, Stephen A. 1983. "Weber, Goethe, and the Nietzschean Allusion: Capturing the Source of the 'Iron Cage' Metaphor." Sociological Analysis 44:297320.

Kloppenberg, James T. 1986. Uncertain Victory: Social Democracy and Progressivism and American Thought, 1870-1920. New York: Oxford University Press.

Koelb, Clayton, ed. 1990. Nietzsche as Postmodernist: Essays Pro and Contra. Albany: State University of New York Press.

Kofman, Sarah. 1993. Nietzsche and Metaphor, translated by Duncan Large. Stanford, Calif.: Stanford University Press.

Lehmann, Jennifer M. 1991. "Durkheim's Women: His Theory of the Structures and Functions of Sexuality." Current Perspectives in Social Theory 11:141-67.

- 1993. Deconstructing Durkheim: A Post-Post Structuralist Critique. New York: Routledge. 
1994. Durkheim and Women. Lincoln: University of Nebraska Press.

Lemert, Charles. 1993. Social Theory: The Multicultural and Classical Readings. Boulder, Colo.: Westview.

Lepenies, Wolf. 1988. Between Literature and Science: The Rise of Sociology, translated by R. J. Hollingdale. Cambridge: Cambridge University Press.

Liebersohn, Harry. 1988. Fate and Utopia in German Sociology, 1870-1923. Cambridge, Mass.: MIT Press.

Love, Nancy S. 1986. Marx, Nietzsche, and Modernity. New York: Columbia University Press.

- 1987. "Epistemology and Exchange: Marx, Nietzsche, and Critical Theory." New German Critique 41:71-94.

Löwith, Karl. 1966. Nature, History, and Existentialism, and Other Essays in the Philosophy of History, edited by Arnold Levison. Evanston, Ill.: Northwestern University Press.

Lukács, Georg. (1962) 1980. The Destruction of Reason, translated by Peter Palmer. London: Merlin Press.

Maffesoli, Michel. 1991. "The Ethic of Aesthetics." Theory, Culture and Society 8:7-20.

- 1993. The Shadow of Dionysus: A Contribution to the Sociology of Orgy. Albany: State University of New York Press.

Mann, Thomas. (1918) 1983. Reflections of a Nonpolitical Man, translated by Walter D. Morris. New York: Frederick Unger.

Mannheim, Karl. (1936) 1955. Ideology and Utopia: An Introduction to the Sociology of Knowledge. New York: Harvest Books.

Marcuse, Herbert. 1964. One-Dimensional Man: Studies in the Ideology of Advanced Industrial Society. Boston: Beacon Press.

- 1966. Eros and Civilization: A Philosophical Inquiry into Freud. Boston: Beacon Press.

- (1945) 1993. "Some Remarks on Aragon: Art and Politics in the Totalitarian Era." Theory, Culture and Society 10:181-95.

Martindale, Don. 1960. The Nature and Types of Sociological Theory, 1st ed. Boston: Houghton Mifflin.

\section{Mifflin.}

Merton, Robert K. 1945. "The Sociology of Knowledge." Pp. 366-405 in TwentiethCentury Sociology, edited by Georges Gurvitch and Wilbert E. Moore. New York: Philosophical Library.

Miller, James. 1978. "Some Implications of Nietzsche's Thought for Marxism." Telos 37:22-41.

- 1993. The Passion of Michel Foucault. Anchor Books: New York.

Mommsen, Wolfgang J. 1974. Max Weber and German Politics 1890-1920, translated by Michael S. Steinberg. Chicago: University of Chicago Press.

1989. The Political and Social Theory of Max Weber. Cambridge: Polity.

Muller, Jerry Z. 1987. The Other God That Failed: Hans Freyer and the Deradicalization of German Conservatism. Princeton, N.J.: Princeton University Press.

Münch, Richard, and Neil J. Smelser. 1993. Theory of Culture. Berkeley and Los Angeles: University of California Press.

Neaman, Elliot Yale. 1993. "Warrior or Esthete? Reflections on the Jünger Reception in France and Germany." New German Critique 59:118-50.

Nehamas, Alexander. 1985. Nietzsche: Life as Literature. Cambridge, Mass.: Harvard University Press.

Nicholson, Linda, ed. 1990. Feminism/Postmodermism. New York: Routledge.

Nietzsche, Friedrich. (1872/1888) 1967. The Birth of Tragedy and The Case of Wagner, translated by Walter Kaufmann. New York: Vintage. 
(1873-76) 1983. Untimely Meditations, translated by R. J. Hollingdale. Cambridge: Cambridge University Press.

- (1878-80) 1986. Human, All Too Human: A Book of Free Spirits, translated by R. J. Hollingdale. Cambridge: Cambridge University Press.

. (1881) 1982a. Daybreak: Thoughts on the Prejudices of Morality, translated by R. J. Hollingdale. Cambridge: Cambridge University Press.

. (1882) 1974. The Gay Science: With a Prelude in Rhymes and an Appendix of Songs, translated by Walter Kaufmann. New York: Vintage.

- (1883-85) 1969c. Thus Spoke Zarathustra, translated by R. J. Hollingdale. London: Penguin.

- (1883-88) 1968b. The Will to Power, translated by Walter Kaufmann and R. J. Hollingdale. New York: Vintage.

(1886) 1966. Beyond Good and Evil: Prelude to a Philosophy of the Future, translated by Walter Kaufmann. New York: Vintage.

. (1887) 1969b. On the Genealogy of Morals, translated by Waiter Kaufmann and R. J. Hollingdale. New York: Vintage.

- (1888) 1969a. Ecce homo, translated by Walter Kaufmann. Pp. 199-335 in On the Genealogy of Morals. New York: Vintage.

- (1888) 1982b. Nietzsche contra Wagner: Out of the Files of a Psychologist. Pp. 661-83 in The Porlable Nietzsche, edited and translated by Walter Kaufmann. New York: Viking Penguin.

- (1888) 1968a. Twilight of the Idols and The Anti-Christ, translated by R. J. Hollingdale. London: Penguin.

Owen, David. 1992. "The Judgement of Nietzsche: Philosophy, Politics, Modernity." History of the Human Sciences 5:121-35.

Parsons, Talcott. (1937) 1968. The Structure of Social Action, 2 vols. New York: Free Press.

Parsons, Talcott, Edward Shils, Kaspar D. Naegele, and Jesse Pitts, eds. 1961. Theories of Society: Foundations of Modern Sociological Theory, 2 vols. New York: Free Press.

Patton, Paul, ed. 1993. Nietzsche and Feminist Theory. New York: Routledge.

Pecora, Vincent P. 1991. "Nietzsche, Genealogy, and Critical Theory." New German Critique 53:104-30.

Peukert, Detlev J. K. 1992. The Weimar Republic: The Crisis of Classical Modernity, translated by Richard Deveson. New York: Hill \& Wang.

Piccone, Paul, ed. 1993-94. "The French New Right: New Right-New Left-New Paradigm." Telos 98/99:3-22.

Pfohl, Stephen. 1993. "Twilight of the Parasites: Ultramodern Capital and the New World Order." Social Problems 2:125-51.

Pütz, Peter. 1981-82. "Nietzsche and Critical Theory." Telos 50:103-14.

1988. "The Problem of Force in Nietzsche and His Critics." Pp. 14-28 in Nietzsche: Literature and Values, edited by Volker Dürr, Reinhold Grimm, and Kathy Harms. Madison: University of Wisconsin Press.

Ricoeur, Paul. 1970. Freud and Philosophy: An Essay on Interpretation, translated by Denis Savage. New Haven, Conn.: Yale University Press.

Ritzer, George. 1992. Sociological Theory. New York: McGraw-Hill.

Robertson, Roland. 1988. "The Sociological Significance of Culture: Some General Considerations." Theory, Culture and Society 5:3-23.

Rosenthal, Bernice Glatzer. 1986. Nietzsche in Russia. Princeton, N.J.: Princeton University Press.

Ross, Edward Alsworth. 1901. Social Control: A Survey of the Foundations of Order. New York: Macmillan.

Roth, Guenther. 1989-90. "Durkheim and the Principles of 1789: The Issue of Gender Equality." Telos 82:71-88. 
Salomon, Albert. 1945. "German Sociology." Pp. 586-614 in Twentieth-Century Sociology, edited by Georges Gurvitch and Wilbert E. Moore. New York: Philosophical Library.

Scaff, Lawrence A. 1989. Fleeing the Iron Cage: Culture, Politics, and Modernity in the Thought of Max Weber. Berkeley and Los Angeles: University of California Press.

Schluchter, Wolfgang. 1989. Rationalism, Religion, and Domination: A Weberian Perspective, translated by Neil Solomon. Berkeley and Los Angeles: University of California Press.

Schmitt, Carl. (1925) 1986. Political Romanticism, translated by Guy Oakes. Cambridge, Mass.: MIT Press.

Schroeder, Ralph. 1987. "Nietzsche and Weber: Two 'Prophets' of the Modern World." Pp. 207-21 in Max Weber, Rationality and Modernity, edited by Scott Lash and Sam Whimster. London: Allen \& Unwin.

Schutte, Ofelia. 1986. Beyond Nihilism: Nietzsche without Masks. Chicago: University of Chicago Press.

Schrift, Alan D. 1990. Nietzsche and the Question of Interpretation: Between Hermeneutics and Deconstruction. New York: Routledge.

Seidman, Steven. 1991. "The End of Sociological Theory: The Postmodern Hope." Sociological Theory 9:131-46.

Seidman, Steven and David Wagner, eds. 1991. Postmodernism and Social Theory: New York: Blackwell.

Shore, Bradd. 1988. "Interpretation under Fire." Anthropological Quarterly 61: 161-76.

Sills, David L, ed. 1968. International Encyclopedia of the Social Sciences, 17 vols. New York: Macmillan and Free Press.

Simmel, Georg. (1900) 1978. The Philosophy of Money, translated by Tom Bottomore and David Frisby. London: Routledge \& Kegan Paul.

- (1907) 1991. Schopenhauer and Nietzsche, translated by Helmut Loiskandl, Deena Weinstein, and Michael Weinstein. Urbana: University of Illinois Press.

Sokel, Walter H. 1993. "The 'Postmodernism' of Ernst Jünger in His Proto-Fascist Stage." New German Critique 59:33-40.

Sorokin, Pitirim A. 1928. Contemporary Sociological Theories. New York: Harper \& Brothers.

- (1937) 1962. Social and Cultural Dynamics, 4 vols. New York: Bedminister Press.

Staude, John Raphael. 1967. Max Scheler. New York: Free Press.

Stauth, Georg, and Bryan S. Turner. 1988. Nietzsche's Dance, Ressentiment, Reciprocity and Resistance in Social Life. Oxford: Basil Blackwell.

- 1992. "Ludwig Klages (1872-1956) and the Origins of Critical Theory." Theory, Culture and Society 9:45-63.

Strauss, Leo. 1989. The Rebirth of Classical Political Rationalism: An Introduction to the Thought of Leo Strauss, edited by Thomas L. Pangle. Chicago: University of Chicago Press.

Strong, Tracy B. 1988. Friedrich Nietzsche and the Politics of Transformation. Expanded ed. Berkeley and Los Angeles: University of California Press.

. 1992. "'What Have We to Do with Morals?' Nietzsche and Weber on History and Ethics." History of the Human Sciences 5:9-18.

Sulloway, Frank J. 1979. Freud, Biologist of the Mind: Beyond the Psychoanalytic Legend. New York: Basic Books.

Taylor, Seth, ed. 1990. Left-Wing Nietzscheans: The Politics of German Expressionism, 1910-1920. New York: Walter de Gruyter.

Thatcher, David S. 1970. Nietzsche in England 1890-1914. Toronto: University of Toronto Press. 
Thomas, R. Hinton. 1986. Nietzsche in German Politics and Society, 1890-1918. Chicago: Open Court.

Timasheff, Nicholas. (1955) 1967. Sociological Theory: Its Nature and Growth. New York: Random House.

Turner, Bryan S. 1982. "Nietzsche, Weber, and the Devaluation of Politics: The Problem of State Legitimacy." Sociological Review 30:367-91.

Turner, Jonathan H. 1991. The Structure of Sociological Theory. Belmont, Calif.: Wadsworth.

Wach, Joachim. 1945. "Sociology of Religion." Pp. 406-37 in Twentieth-Century Sociology, edited by Georges Gurvitch and Wilbert E. Moore. New York: Philosophical Library.

Ward, Lester F. 1903. Pure Sociology: A Treatise on the Origin and Spontaneous Development of Sociology. New York: Macmillan.

Warren, Mark. 1988. Nietzsche and Political Thought. Cambridge, Mass.: MIT Press.

- 1992. "Max Weber's Nietzschean Conception of Power." History of the Human Sciences 5:19-37.

Weber, Marianne. (1926) 1975. Max Weber: A Biography, translated and edited by Harry Zohn. New York: Wiley.

Weber, Max. (1904-17) 1949. The Methodology of the Social Sciences, translated and edited by Edward A. Shils and Henry A. Finch. Glencoe, Ill.: Free Press.

- (1917) 1958b. "Religious Rejections of the World and Their Directions." Pp. 323-59 in From Max Weber, translated and edited by H. H. Gerth and C. Wright Mills. New York: Oxford University Press.

- [1919] 1958c. "Science as a Vocation." Pp. 129-56 in From Max Weber, translated and edited by H. H. Gerth and C. Wright Mills. New York: Oxford University Press.

- (1904-5) 1958a. The Protestant Ethic and the Spirit of Capitalism, translated by Talcott Parsons. New York: Scribner's.

- (1921) 1968. Economy and Society, vol. 1. Edited by Guenther Roth and Claus Wittich. New York: Bedminster Press.

Zeitlin, Irving M. 1994. Nietzsche: A Re-Examination. Cambridge: Polity.

Zimmerman, Michael E. 1990. Heidegger's Confrontation with Modernity: Technology, Politics, and Art. Bloomington: Indiana University Press. 